This document classified by:

UC-11, Environmental

Name R. E. Isaacson

Title Manager - Physical and Life \& Earth Sciences

UC-70,

Waste Management

\title{
241-T-106 TANK LEAK INVESTIGATION
}

Prepared by

Research Department

Research and Engineering Division

November 1973

\section{ATLANTIC RICHFIELD HANFORD COMPANY \\ RICHLAND, WASHINGTON}

Operated for the Atomic Energy Commission by A tlantic Richfield Hanford Company under Contract AT(45-1)-2130

This report was prepared as an account of work Whited States Government. Neither the United States nor the United States Atomic Energy Comission, hor any of their employees, nor any of their contractors, subcontractors, or their employees,

makes any warranty, express or implied, or assumes any

legal liability or responsibility for the accuracy, completeness or usefuiness of any information, apparatus,
product or process disclosed, or represents that its use would not infringe privately owned rights. 


\section{DISCLAIMER}

This report was prepared as an account of work sponsored by an agency of the United States Government. Neither the United States Government nor any agency Thereof, nor any of their employees, makes any warranty, express or implied, or assumes any legal liability or responsibility for the accuracy, completeness, or usefulness of any information, apparatus, product, or process disclosed, or represents that its use would not infringe privately owned rights. Reference herein to any specific commercial product, process, or service by trade name, trademark, manufacturer, or otherwise does not necessarily constitute or imply its endorsement, recommendation, or favoring by the United States Government or any agency thereof. The views and opinions of authors expressed herein do not necessarily state or reflect those of the United States Government or any agency thereof. 


\section{DISCLAIMER}

Portions of this document may be illegible in electronic image products. Images are produced from the best available original document. 


\section{ABSTRACT}

On June 8,1973 , the $241-\mathrm{T}-106$ underground liquid waste storage tank, located on the U.S. Atomic Energy Commission's Hanford reservation, was confirmed as leaking. It was predicted that the leaked waste would be retained by the dry sediments well above the water table. A study was instigated to confirm this prediction. Results show the deepest penetration observed was 27 meters below the ground surface or 35 meters above the water table (approximately 87 and 116 feet, respectively). Based on these results and the basic knowledge of liquid movement in Hanford sediments, further movement of the radioactivity from its present location will be negligible. 


\section{1-T-106 TANK LEAK INVESTIGATION}

\section{INTRODUCTION}

On June 8, 1973, the 241-T-106 underground liquid waste storage tank, located in the 200 West Area of the U.S. Atomic Energy Commission's Hanford reservation, was confirmed as leaking. The location of the 241-T-106 tank in relation to the Hanford reservation and to the state of Washington is shown in Figure 1.

Subsequent investigation of this $\operatorname{tank}^{(1)}$ revealed that 435 cubic meters $(115,000$ gallons) of radioactive liquid waste had leaked into the adjacent sediments. Soon after the leak volume and the radiochemical constituents of the waste liquid were determined, the Research Depart- ment of the Atlantic Richfield Hanford Company predicted that the waste liquid would remain in the dry sediments near the 241-T-106 tank and would not percolate to the underlying water table. This prediction was based on knowledge of the geology and hydrology underlying the 241-T tank farm and on more than 20 years of experience with liquid waste effluents in 200 West Area sediments.

To confirm this prediction, a study was instigated by the Research Department to define the boundary of the contaminated zone and the depth to which this liquid waste had percolated toward the water table. The results of this investigation are presented in this report.

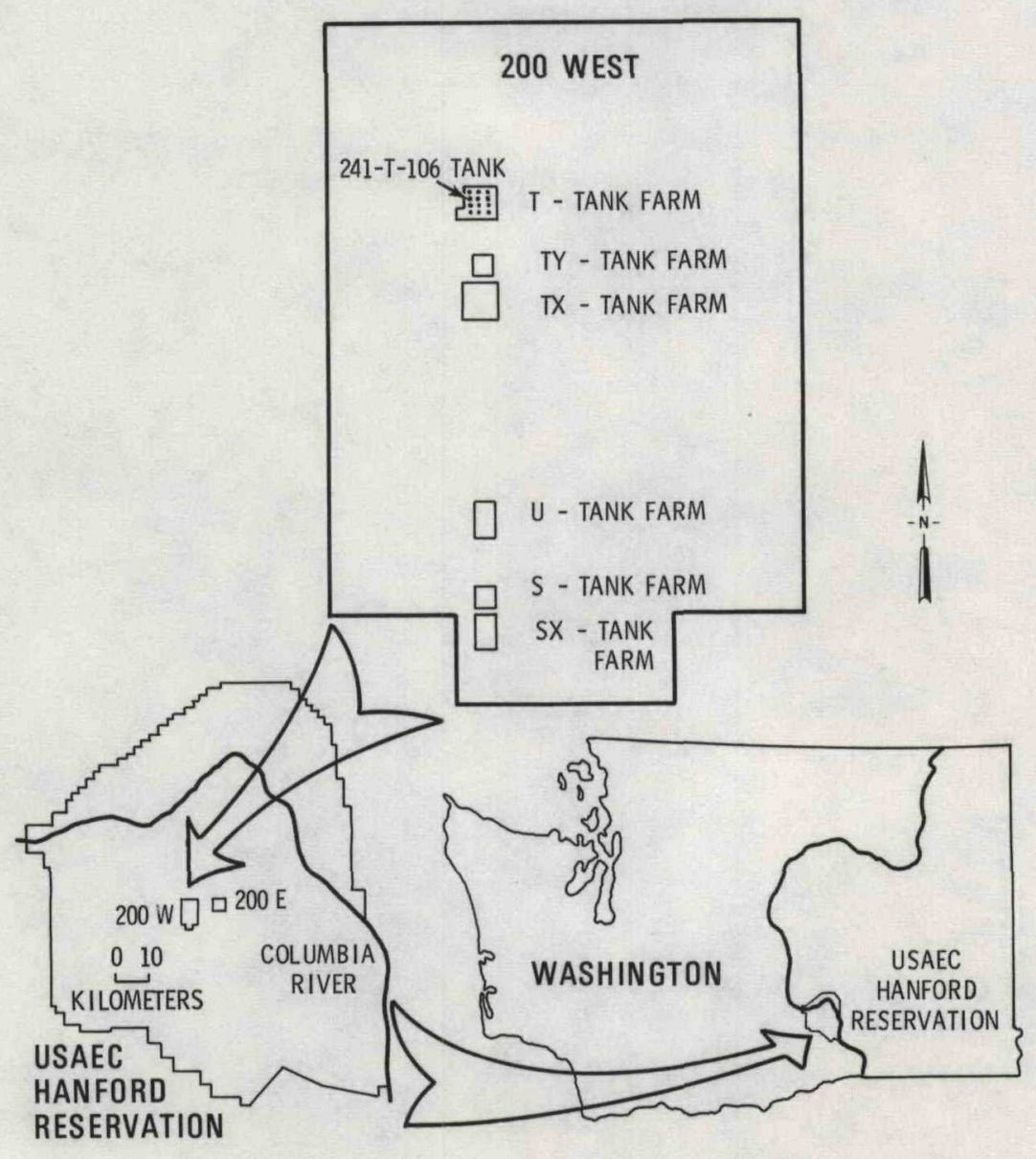

FIGURE 1. Map Showing Location of 241-T-106 Tank in Relation to the Hanford Reservation and the State of Washington 


\section{SUMMARY}

Approximately 435 cubic meters of radioactive liquid waste leaked into the sediments adjacent to the 241-T-106 tank. It was predicted that the leaked waste would be retained by the dry sediments well above the water table. To confirm this prediction, 16 wells were drilled to delineate the contaminated zone. The deepest penetration observed in the wells drilled was 27 meters below ground surface or 35 meters above the water table (approximately 87 and 116 feet, respectively). The one microcurie per liter ruthenium isopleth was used to delin- eate the contaminated zone. The volume of sediments was calculated to be about 25,000 cubic meters.

Four wells, drilled north and east of the 241T-106 tank, encountered leakage of liquid waste resulting from a failed grout seal in a spare fill line. The one microcurie per liter ruthenium isopleth was also used to delineate the contaminated zone associated with this leak. The volume of sediments enclosed by the envelope thus defined was determined to be about 1,700 cubic meters. The greatest depth to which this liquid waste penetrated is about 25 meters below the ground surface, or about 37 meters above the water table. 


\section{GEOLOGICAL SETTING}

At the time of the 241-T-106 tank leak five groundwater monitoring wells and seven leak detection wells were existing near the 241-T tank farm. The groundwater monitoring wells range in depth from 70 to 95 meters, and the leak detection wells are 46 meters below the ground surface. (2) The geological information obtained from these wells and the 16 new wells drilled to characterize the 241-T-106 tank leak is plotted on a plane cutting the ground surface at right angles through the center of the 241-T tank farm (Figure 2). $(3,4)$ Information obtained from this cross section made it possible to visualize how the various types of sediments were distributed beneath this tank farm and to interpret how these sediments would influence the rate and direction of liquid waste movement.

The material around and over the tanks consists of local sediments, excavated from the ground prior to tank construction. The backfill material is predominantly coarse sand, silt, and gravel (Table I). Backfill material is easily recognized because the materials are well mixed. In contrast, the undisturbed sedi- ments exi ure 3 ). T materials ground su

Beneat

25 meters ments are and (b)). called gla shows the report as gravel, al materials and mediu materials the north floodwate waters to reservatic attitude of In the 200 planes dip Underl a deposit the 241-T three met

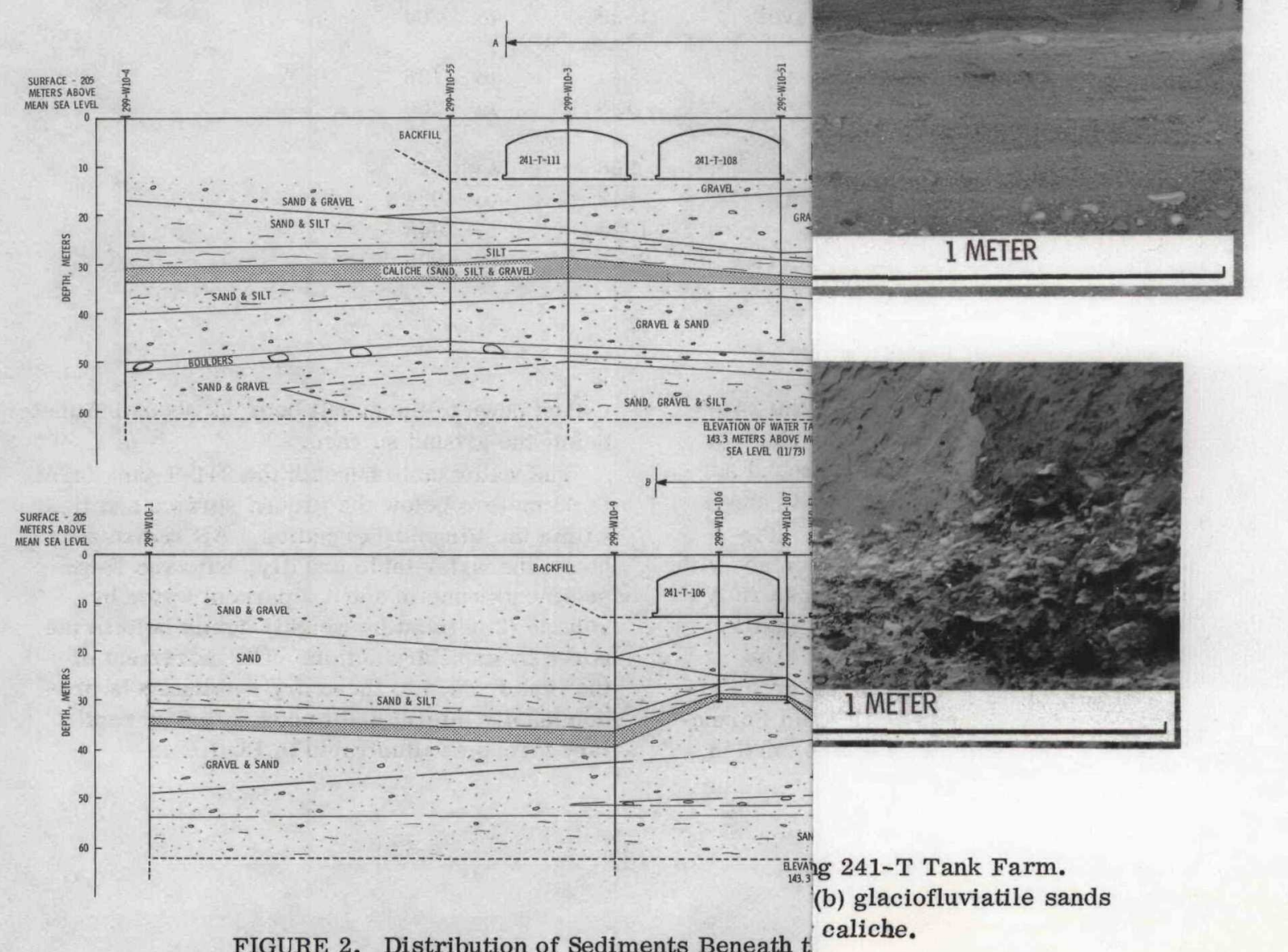


TABLE I

GRAIN SIZE DEFINITIONS OF SEDIMENTARY MATERIALS AS USED IN THIS REPORT AND IN COMMON USAGE IN HANFORD GEOLOGIC RESEARCH ${ }^{(5)}$

\begin{tabular}{|c|c|c|c|}
\hline Description & \multicolumn{3}{|c|}{ Diameter (mm) } \\
\hline Very fine clay & 0.00024 & to & 0.00049 \\
\hline Fine clay & 0.00049 & to & 0.00098 \\
\hline Medium clay & 0.00098 & to & 0.00195 \\
\hline Coarse clay & 0.00195 & to & 0.0039 \\
\hline Very fine silt & 0.0039 & to & 0.0078 \\
\hline Fine silt & 0.0078 & to & 0.0156 \\
\hline Medium silt & 0.0156 & to & 0.0313 \\
\hline Coarse silt & 0.0313 & to & 0.0625 \\
\hline Very fine sand & 0.0625 & to & 0.125 \\
\hline Fine sand & 0.125 & to & 0.25 \\
\hline Medium sand & 0.25 & to & 0.50 \\
\hline Coarse sand & 0.5 & to & 1 \\
\hline Very coarse sand & 1 & to & 2 \\
\hline Very fine gravel & 2 & to & 4 \\
\hline Fine gravel & 4 & to & 8 \\
\hline Medium gravel & 8 & to & 16 \\
\hline Coarse gravel & 16 & to & 32 \\
\hline Very coarse gravel & 32 & to & 64 \\
\hline Small cobbles & 64 & to & 128 \\
\hline Large cobbles & 128 & to & 256 \\
\hline Small boulders & 256 & to & 512 \\
\hline Medium boulders & 512 & to & 1024 \\
\hline Large boulders & 1024 & to & 2048 \\
\hline Very large boulders & 2048 & to & 4096 \\
\hline
\end{tabular}

Underlying the eolian deposit under the 241-T tank farm is a caliche layer, the top surface of which lies 27 to 33 meters below the ground surface. The caliche consists of sand, silt, and gravel cemented by calcium carbonate. Figure 3 (c) shows the wind-blown silt in contact with the caliche. The caliche horizon is a naturallyformed, concrete-like material and is easily recognized in the field during drilling. The caliche was formed on the surface of a group of sediments collectively called the Ringold Formation. $(7,8)$ Sediments of the Ringold Formation extend down to the basalt bedrock about 145 meters below the ground surface.

The water table beneath the 241-T tank farm is 62 meters below the ground surface and lies within the Ringold Formation. All sediments above the water table are dry, but even these sediments contain about 5 percent water by volume ( 2 percent by weight) tightly held in the pores by capillary action. The movement of the liquid added to these dry sediments is predominantly lateral and is controlled by capillary forces as illustrated in Figure 4. 


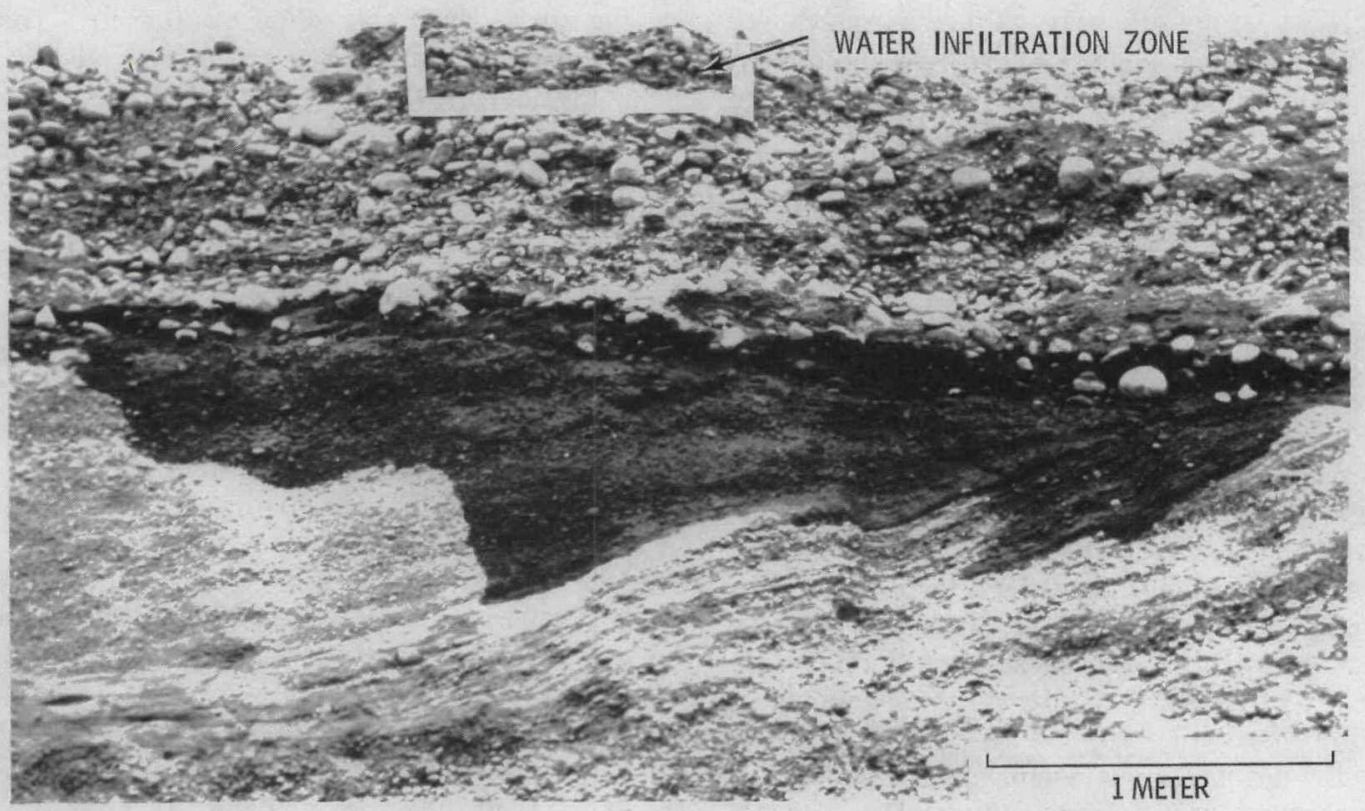

(a)

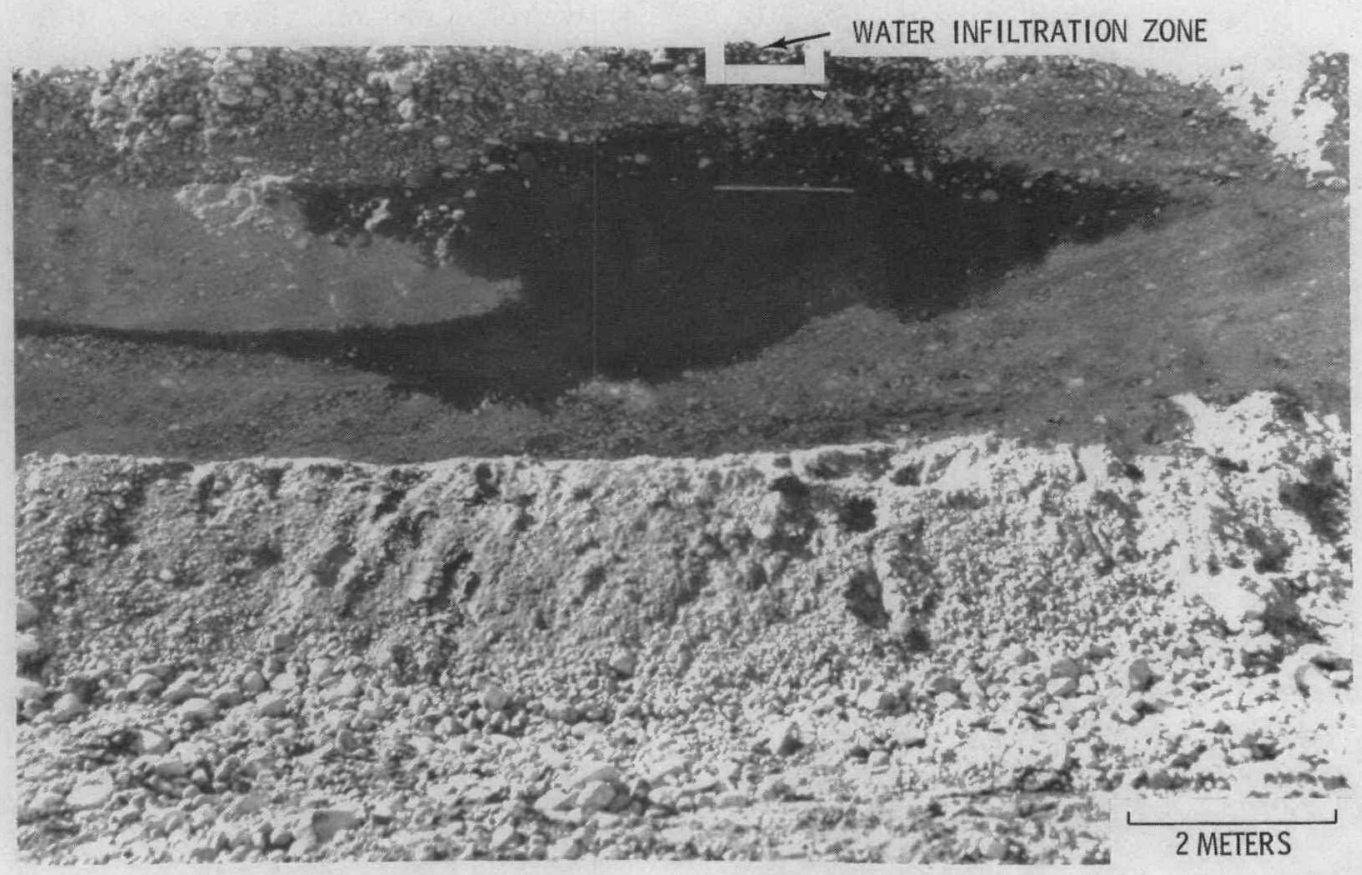

(b)

FIGURE 4. Typical Horizontal and Vertical Movement of Liquid in Glaciofluviatile Sediments. (a) After 6 hours (b) after 24 hours. 


\section{LEAK INVESTIGATION}

On June 8, 1973, the 241-T-106 (T-106) tank was confirmed as a leaking high-level radioactive waste storage tank. The events leading up to the discovery of the leak and the actions taken to completely drain the tank were documented in a report issued July, 1973. (1) On June 12, 1973, ARHCO's Research Department initiated a study to delineate the contaminated zone and to confirm the predicted extent of movement.

To define the boundary of the contaminated zone, wells were drilled in the vicinity of the T-106 tank and the depths and concentrations of radioactivity recorded where encountered. As a well was completed the data were evaluated and compared to the travel predicted. The results of these actions established the best possible location for the next well to be drilled. A total of 16 new wells were drilled as part of this investigation. Two existing monitoring wells were utilized in this study.

As each new well was drilled, sediment samples were taken at 1.5 -meter intervals. The sediment samples obtained during drilling were packaged and sealed immediately. Samples from contaminated zones were then sent to ARHCO's Chemical Technology Laboratory for analysis. (9) At the completion of drilling, a gamma ray detector was lowered down the well to determine the depth of the contaminated zones.

Because the primary objective of this study was to confirm as quickly as possible the concentration and the depth to which the waste liquid had percolated, only the most rapid method of analysis was used. Consequently a gamma energy spectrometer was employed, a method of analysis which measures quantities of radionuclides which decay by gamma emission. Strontium-90 does not emit a gamma ray directly in its decay. However, strontium-90 has a very high energy beta particle which interacts with surrounding atoms to produce a continium of secondary gamma rays (known as bremsstrahlung radiation)。 These secondary gamma rays can be detected by this analytical system.

\section{BOUNDARY OF CONTAMINATED ZONE}

As predicted the highest concentrations of radionuclides were encountered in the region where wells $299-\mathrm{W} 10-106,299-\mathrm{W} 10-107$, 299-W10-110, and 299-W10-111 were drilled. These wells are located southeast of the T-106 tank (Figure 5). The available data suggest that the T-106 tank leak was between wells 299-W10106 and 299-W10-111, probably closer to $299-$ W10-106 because the highest concentrations of radionuclides occur at a higher elevation (see A ppendix)。

Several wells drilled north and east of the T-106 tank encountered radioactivity near the 241-T-103 tank. Subsequent investigations revealed that a leak resulted from a faıled grout seal in a spare fill entry line. The volume of liquid lost has been determined to be on the order of five cubic meters. The extent to which this waste liquid spread laterally and vertically is shown in Figures 6 and 7. The data also show that this radioactivity has preferentially moved toward the southeast. The one microcurie per liter ruthenium isopleth was also used to delineate the contaminated zone associated with this leak. The volume of sediments was determined to be about 1,700 cubic meters. The greatest depth to which the liquid waste from the T-103 fill line penetrated is about 25 meters below the ground surface, or about 37 meters above the water table. 

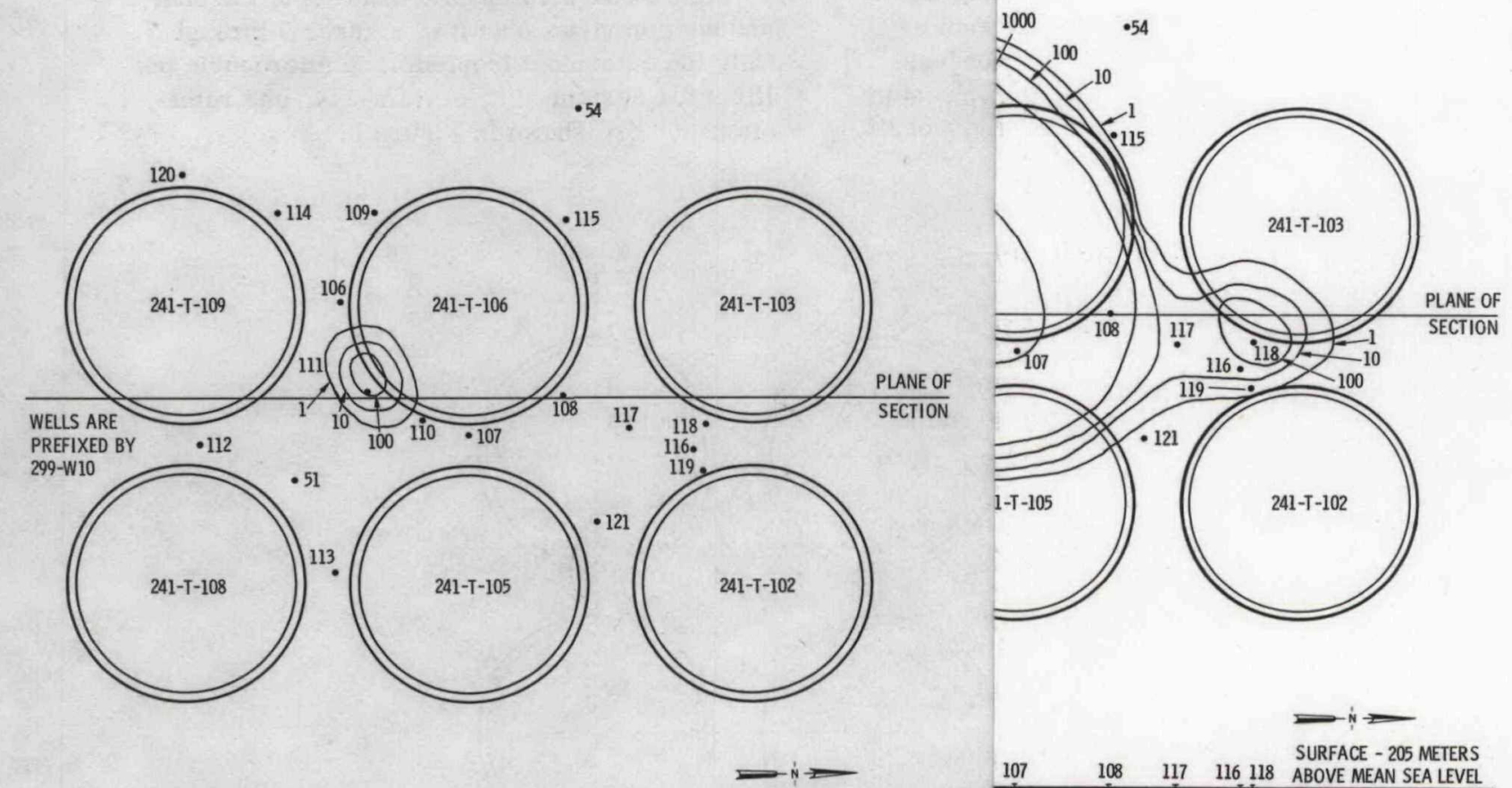

SURFACE - 205 METERS
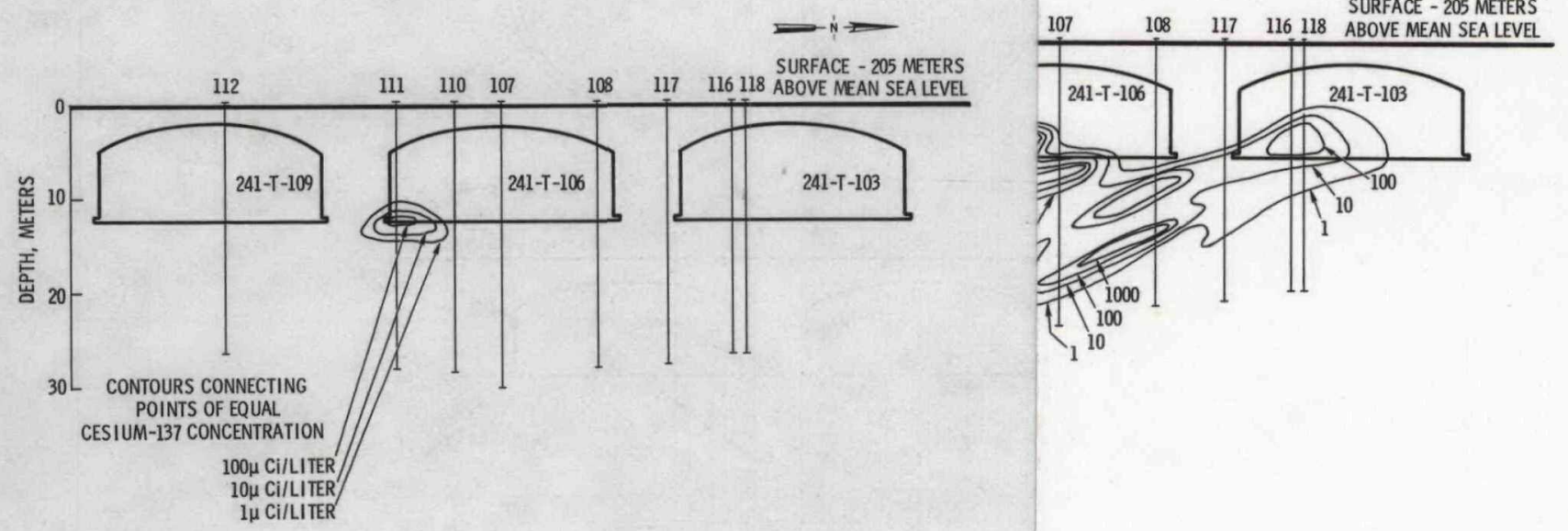

FIGURE 5. Concentration Distribution of Cesium-137

1 Distribution of Ruthenium-106 


\section{RELATIVE MOVEMENT OF RADIONUCLIDES}

An assessment of the relative movement of radionuclides from the $T-106$ tank can be made from the gamma activity analyses reported in the Appendix. The data from the samples analyzed show the relative mobility of the radionuclides in this system to be (in order of least mobility to greatest mobility) plutonium, cesium, strontium, europium, cerium, antimony, cobalt, and ruthenium. Figures 5 through 7 show in both plan view and in section view the concentration distribution of cesium-137, cerium-144, and ruthenium-106, radionuclides representative of this range of mobility.

Figure 8 is a composite drawing of the plan and section views shown in Figures 5 through 7 . Only the outermost isopleth (one microcurie per liter) for cesium-137, cerium-144, and ruthenium-106 are shown in Figure 8.
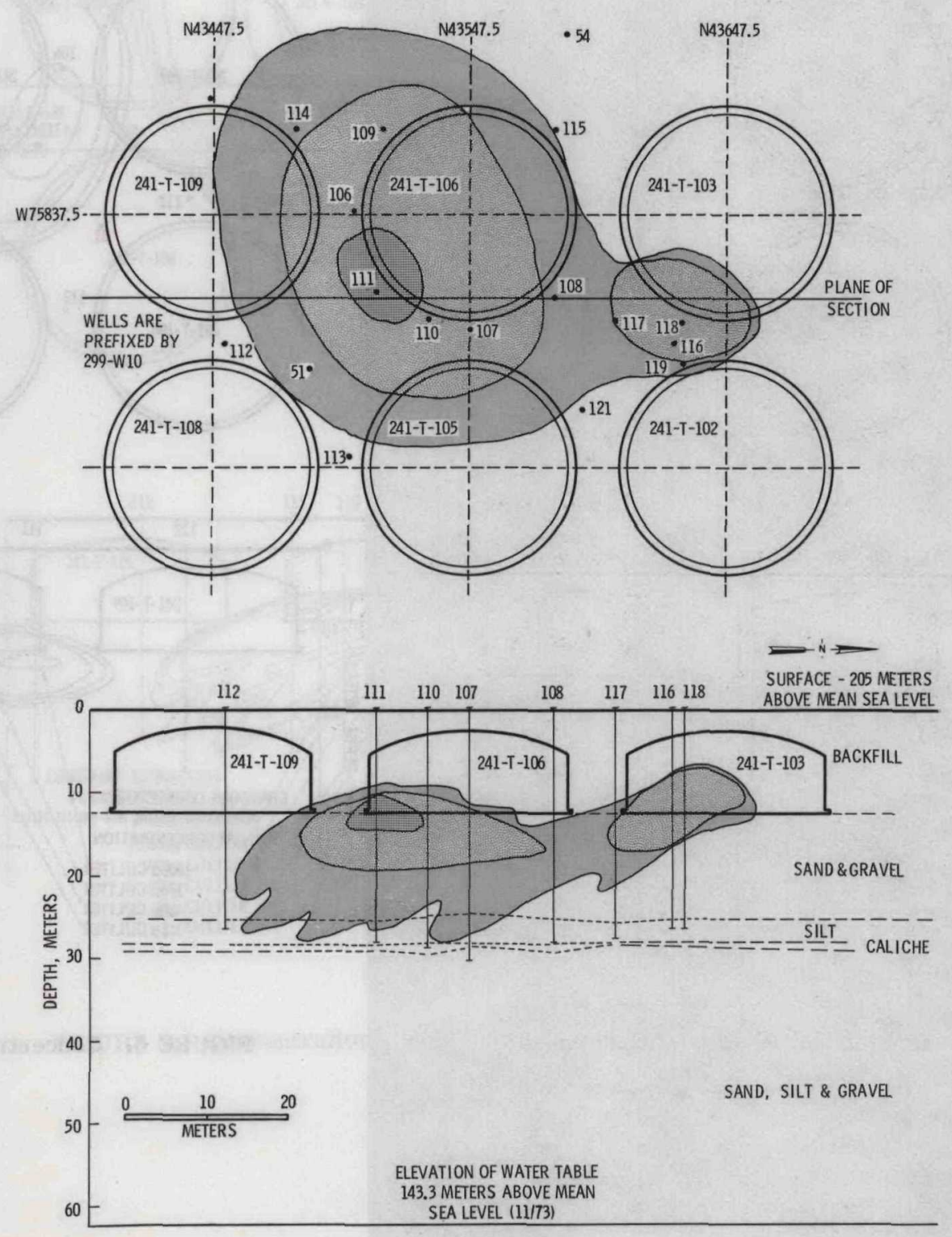

FIGURE 8. Composite Drawing of Plane and Section Views of the $\mu \mathrm{Ci} /$ liter Concentration Distributions Shown in Figures 5 Through 7 
An evaluation of these data indicate that as predicted a large portion of radionuclide activity remains in a relatively small volume near the T-106 tank. Although the leaked liquid waste contained approximately four curies of plutonium, plutonium was not detected in any well drilled. Experience at Hanford has shown that plutonium in neutral and basic solutions does not migrate more than about a meter into the sediments from the point of release. The wells drilled around the perimeter of the T-106 tank are no closer than 1.5 meters to the tank. On the basis of past experience, it can be reasonably assumed that the four curies of plutonium are contained in the sediments close to the leak point.

Of the radionuclides detected, cesium- 137 was distributed in the smallest volume of sediments. This, too, is in accord with prior experience at Hanford. In all instances where cesium-137 was found to be present, there was characteristic bremsstrahlung radiation indicating the presence of strontium-90. In this liquid waste, which contains a high concentration of carbonate ion and has a high $\mathrm{pH}$, strontium carbonate can be expected to precipitate and thus the sorption of strontium-90 may actually be as high or higher than that of cesium-137. (10) Isopleths showing cesium-137 distribution are shown in Figure 5.
Europium-155 and cerium-144 are the second most strongly sorbed. Isopleths showing cerium144 distribution are given in Figure 6. Short half-lived (less than six years) radionuclides, antimony-125, cobalt- 60 , and ruthenium-106, are the most poorly sorbed of the radionuclides present in this waste liquid. Isopleths for ruthenium106 are given in Figure 7.

It is important to note that about 70 percent of the activity which leaked into the sediments has remained within a sediment volume of about 314 cubic meters (an ellipsoid with radii 5 meters, 6 meters, and 2.5 meters). A reasonable estimate of the maximum leak volume can be approximated by the one microcurie per liter ruthenium106 isopleth, enclosing a soil volume of about 25,000 cubic meters (an ellipsoid with radii 21 meters, 28 meters and 10 meters) (Figure 7). Figure 9 shows the zone of contamination with respect to the T-106 tank, the local geology, and the distance to the underlying water table.

The results of this study confirm the predictions made soon after the leak was discovered. Based on these results and the basic knowledge of liquid movements in Hanford sediments established since the start of plant operations, further movement of the radioactivity from its present location will be negligible. 

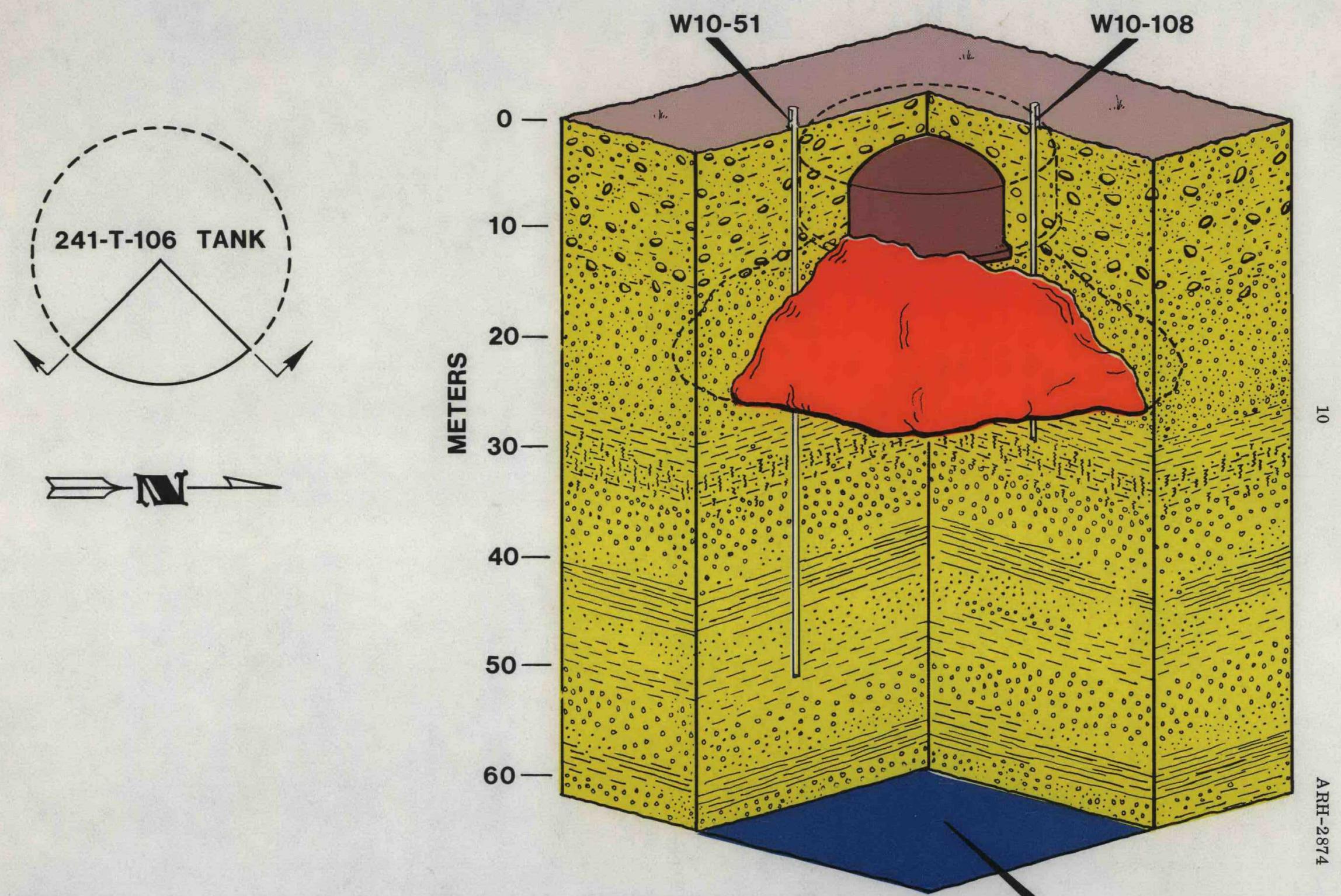

FIGURE 9. Three-Dimensional Drawing of Zone of Contamination with Respect to the T-106 Tank, the Local Geology, and the Distance to the Underlying Water Table

POSITION OF WATERTABLE 11-73 


\section{REFERENCES}

1. AEC-RL, Richland, Washington, "Report on the 106-T Tank Leak at the Hanford Reservation, Richland, Washington, July 1973."

2. K. L. Kipp, V. L. McGhan, and D. W. Damschen, Hanford Wells, BNWL-1739, June 1973.

3. D. J. Brown, "Geology Underlying 200 A rea Tank Farms," HW-67729, December 1960.

4. D. J. Brown, "Subsurface Geology of the Hanford Separations Areas," HW-61780, October 1959 .

5. National Research Council, "Report of the Subcommittee on Sediment Terminology, ' Trans。Am. Geophys Union, vol. 28, No. 6, December 1947.

6. D. J. Brown, "An Eolian Deposit Beneath 200 West Area," HW-67549, December 1960.
7. D. J. Brown, and R. E. Brown, "The Ringold Formation and Its Relationships to Other Formations," HW-SA-2319, November 1961.

8. R. C. Newcomb, "Ringold Formation of Pleistocene Age in Type Locality, The White Bluffs, Washington," Amer. J. Sci., vol. 256, pp. $238-340,1958$.

9. M. C. Metz and W. H. Zimmer, "Preliminary 241-T-106 Tank Leak Investigation," ARH-2874 PRE, October 1973.

10. K. E. Cowser, R. J. Morton, and E. J. Witkowski, "The Treatment of Large-Volume, Low-Level Waste by the Lime-Soda Process," Proc. of the 2nd U. N. Internat'l Conference on the Peaceful Uses of Atomic Energy, Geneva, Pater P12354, vol. 18, p. 161, 1958.

11. D. J. Brown, "Migration Characteristics of Radionuclides Through Sediments Underlying the Hanford Reservation, "ISO-SA-32 (unclassified), IAEA Symposium, May 1967. 


\section{APPENDIX}

EXPLANATION: Gamma Log:

Gamma Energy Analyses:

Illustrates count rate (counts per second) as a function of depth for each well. Initial gamma log shown as solid line, latest gamma log as dashed line. Expandedscale inserted where activity too small to be expressed by scale of $5 \times 10^{5}$.

Lithology: General description of sediments logged at well-site during drilling.

Listing of radionuclide concentrations (millicuries per liter) from each well as a function of depth.

Dash indicates radionuclide is absent or below limit of detection. The lowest concentration reported for each radionuclide is as follows:

$\underline{\text { Radionuclide }}$

Europium-155

Europium-154

Cerium-144

Antimony -125

Ruthenium-106

Cesium-137

Cobalt-60

$$
\underline{\mu \mathrm{Ci} / \text { liter }}
$$

0.00086

0.534

0.0601

0.443

0.0018

0.00705

0.0408
Well No.

$$
\begin{aligned}
& 299-\mathrm{W} 10-110 \\
& 299-\mathrm{W} 10-118 \\
& 299-\mathrm{W} 10-117 \\
& 299-\mathrm{W} 10-118 \\
& 299-\mathrm{W} 10-106 \\
& 299-\mathrm{W} 10-106 \\
& 299-\mathrm{W} 10-119
\end{aligned}
$$

Time Zero: For comparative purposes radionuclide values recalculated, in order to compensate for radioactive decay, as if all samples analyzed June 21, 1973.

A sterisk indicates depths from which samples were not submitted to laboratory for analysis. 
LITHOLOGIC DESCRIPTION \& GAMMA LOG OF INVESTIGATION WELL

299-W10-106

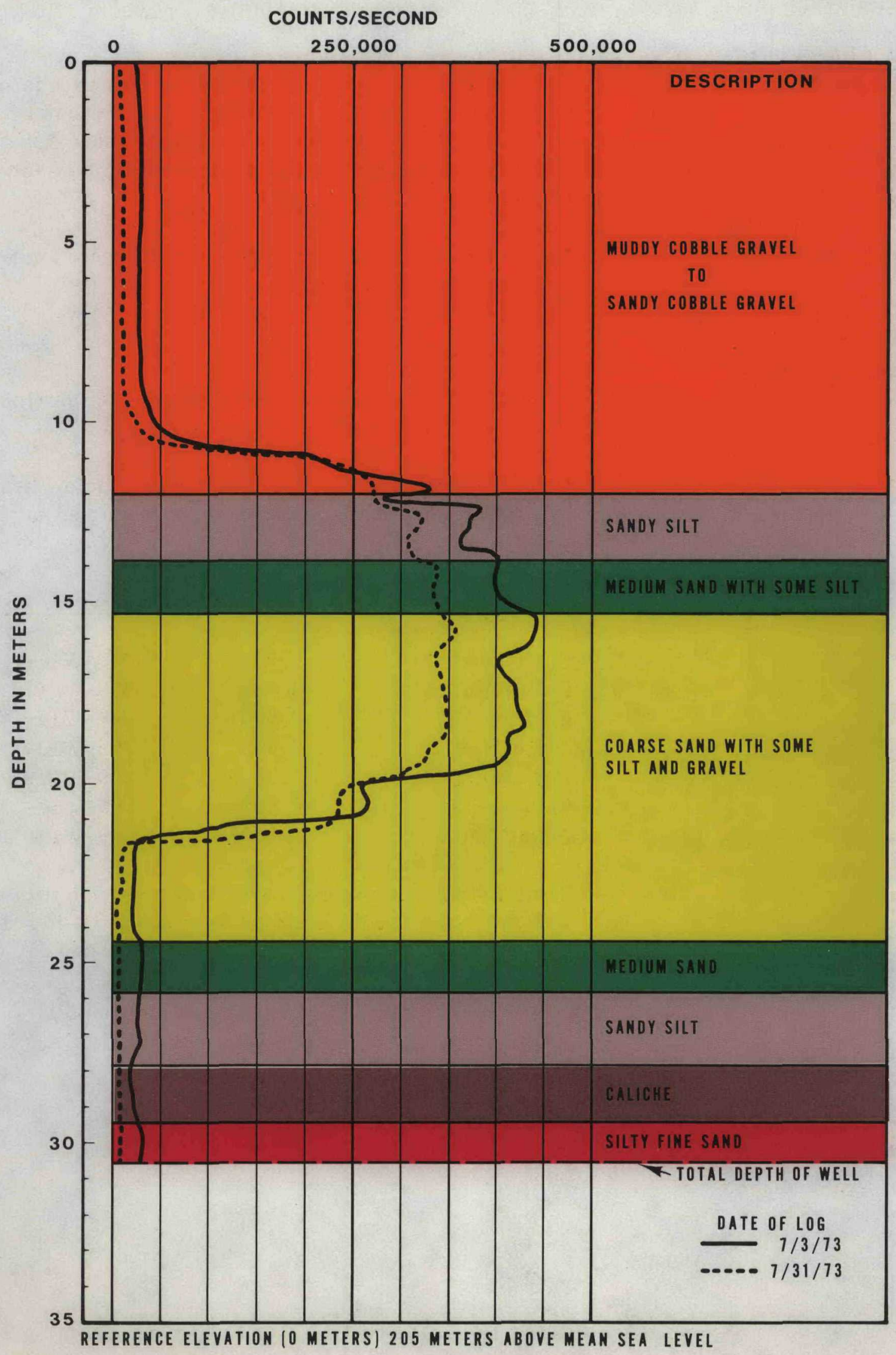


GAMMA ENERGY ANALYSES OF SAMPLES

FROM WELL 299-W10-106

\begin{tabular}{|c|c|c|c|c|c|c|c|}
\hline $\begin{array}{r}\text { Meters } \\
\text { Depth }\end{array}$ & $155_{\mathrm{Eu}}$ & ${ }^{144} \mathrm{Ce}$ & $125 \mathrm{Sb}$ & $\frac{\mu \mathrm{Ci} / \text { liter }}{106 \mathrm{Ru}}$ & $137 \mathrm{Cs}$ & ${ }^{154} \mathrm{Eu}$ & ${ }^{60} \mathrm{Co}$ \\
\hline \multicolumn{8}{|l|}{9.1 * } \\
\hline 10.7 & 127 . & 1,070 & 103 & 15,600 & & 221 & 68.9 \\
\hline 12.2 & 71.1 & 612 & 57.1 & 3,870 & - & 130 & - \\
\hline 13.7 & 88.7 & 886 & 74.0 & 7,300 & - & 155 & 37.1 \\
\hline 15.2 & 78.1 & 536 & 57.7 & 9,160 & - & 131 & 67.8 \\
\hline 16.8 & 98.6 & 787 & 71.9 & 9,290 & - & 162 & 50.1 \\
\hline 18.3 & 51.7 & 346 & 48.5 & 12,000 & - & 97.0 & 60.4 \\
\hline 19.8 & - & - & - & 67.5 & - & - & - \\
\hline 21.3 & - & - & - & 2.21 & - & - & - \\
\hline 22.9 & - & - & - & 0.171 & 0.00705 & - & - \\
\hline 24.4 & - & - & - & 10.2 & - & - & - \\
\hline \multicolumn{8}{|l|}{$25.9^{*}$} \\
\hline 27.4 & - & - & - & 0.0394 & - & - & - \\
\hline 29.0 & - & - & - & 0.0533 & - & - & - \\
\hline
\end{tabular}

- Radionuclide is absent or below limit of detection. Time Zero is June 21, 1973.

*Samples not submitted to laboratory for analysis. 
LITHOLOGIC DESCRIPTION \& GAMMA LOG OF INVESTIGATION WELL 299-W10-107

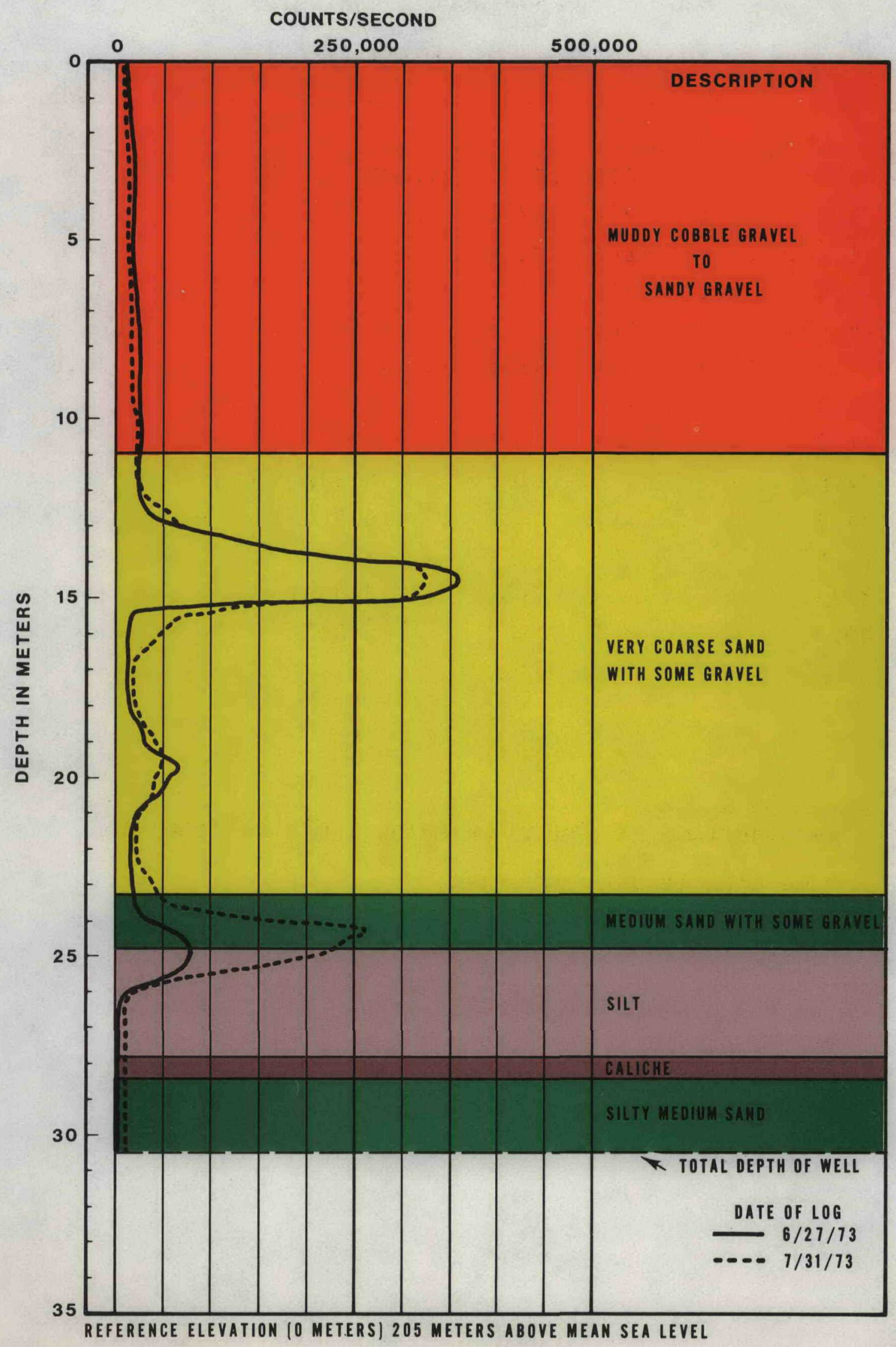


GAMMA ENERGY ANALYSES OF SAMPLES

FROM WELL 299-W10-107

\begin{tabular}{|c|c|c|c|c|c|c|c|}
\hline \multirow{2}{*}{$\begin{array}{r}\text { Meters } \\
\text { Depth } \\
\end{array}$} & \multicolumn{7}{|c|}{$\mu \mathrm{Ci} /$ liter } \\
\hline & ${ }^{155} \mathrm{Eu}$ & ${ }^{144} \mathrm{Ce}$ & $125 \mathrm{Sb}$ & ${ }^{106} \mathrm{Ru}$ & $137 \mathrm{Cs}$ & ${ }^{154} \mathrm{Eu}$ & ${ }^{60} \mathrm{Co}$ \\
\hline \multicolumn{8}{|l|}{9.1 * } \\
\hline \multicolumn{8}{|l|}{$10.7^{*}$} \\
\hline \multicolumn{8}{|l|}{$12.2^{*}$} \\
\hline 13.7 & 57.6 & 278 . & 49.7 & 10,700 . & - & 16.5 & 5.92 \\
\hline \multicolumn{8}{|l|}{$15.2^{*}$} \\
\hline \multicolumn{8}{|l|}{$16.8^{*}$} \\
\hline 18.3 & - & - & - & 3.57 & - & - & - \\
\hline \multicolumn{8}{|l|}{$19.8^{*}$} \\
\hline \multicolumn{8}{|l|}{$21 \cdot 3^{*}$} \\
\hline \multicolumn{8}{|l|}{$22.9^{*}$} \\
\hline 24.4 & - & - & 2.29 & 613. & - & - & - \\
\hline \multicolumn{8}{|l|}{$25.9^{*}$} \\
\hline 27.4 & - & - & - & 1.73 & - & - & - \\
\hline $29.0^{*}$ & & & & & & & \\
\hline
\end{tabular}

- Radionuclide is absent or below limit of detection.

Time Zero is June 21, 1973.

*Samples not submitted to laboratory for analysis. 


\section{A-5}

LITHOLOGIC DESCRIPTION \& GAMMA LOG OF INVESTIGATION WELL 299-W10-108

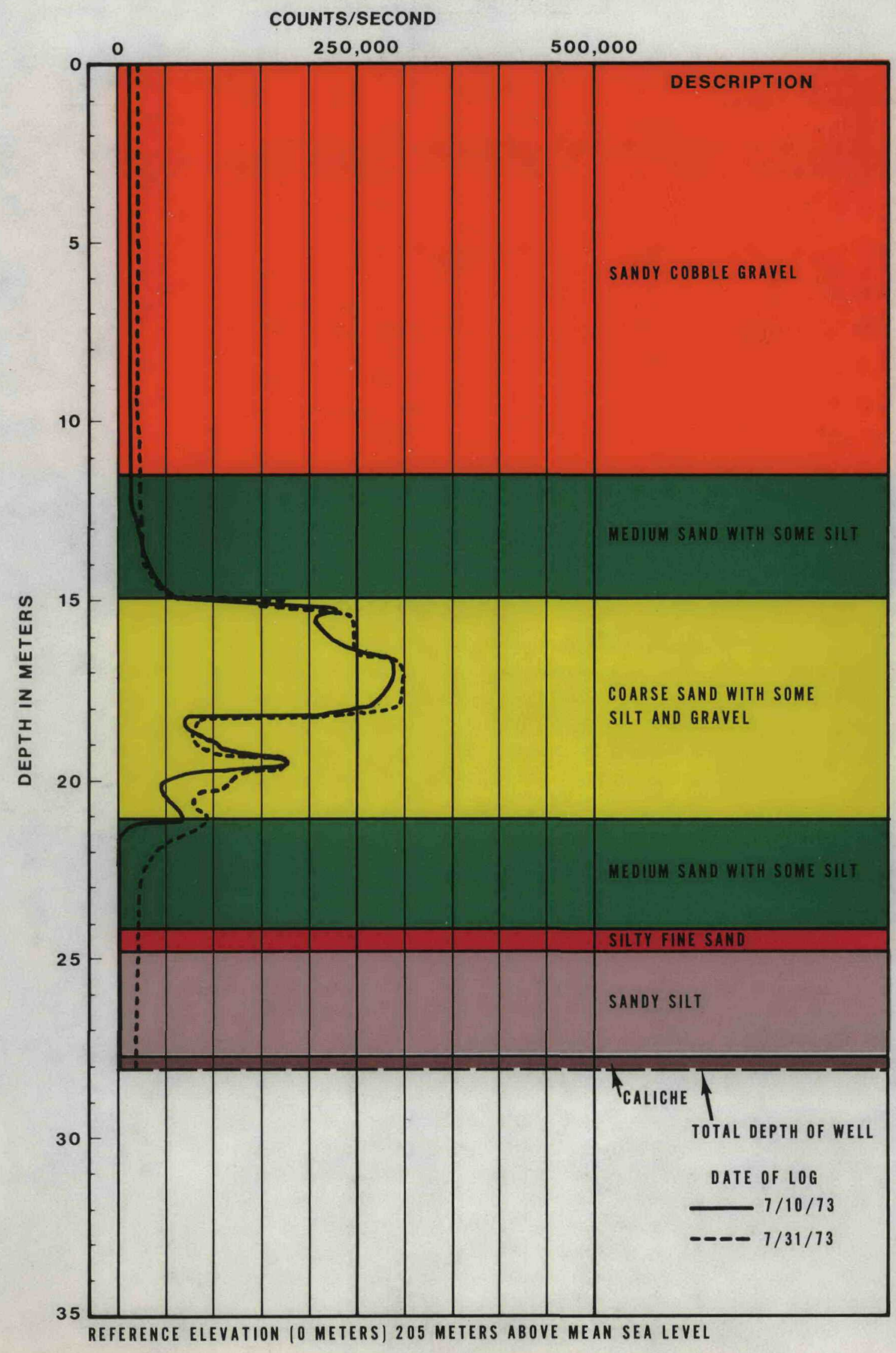


GAMMA ENERGY ANALYSES OF SAMPLES

FROM WELL 299-W10-108

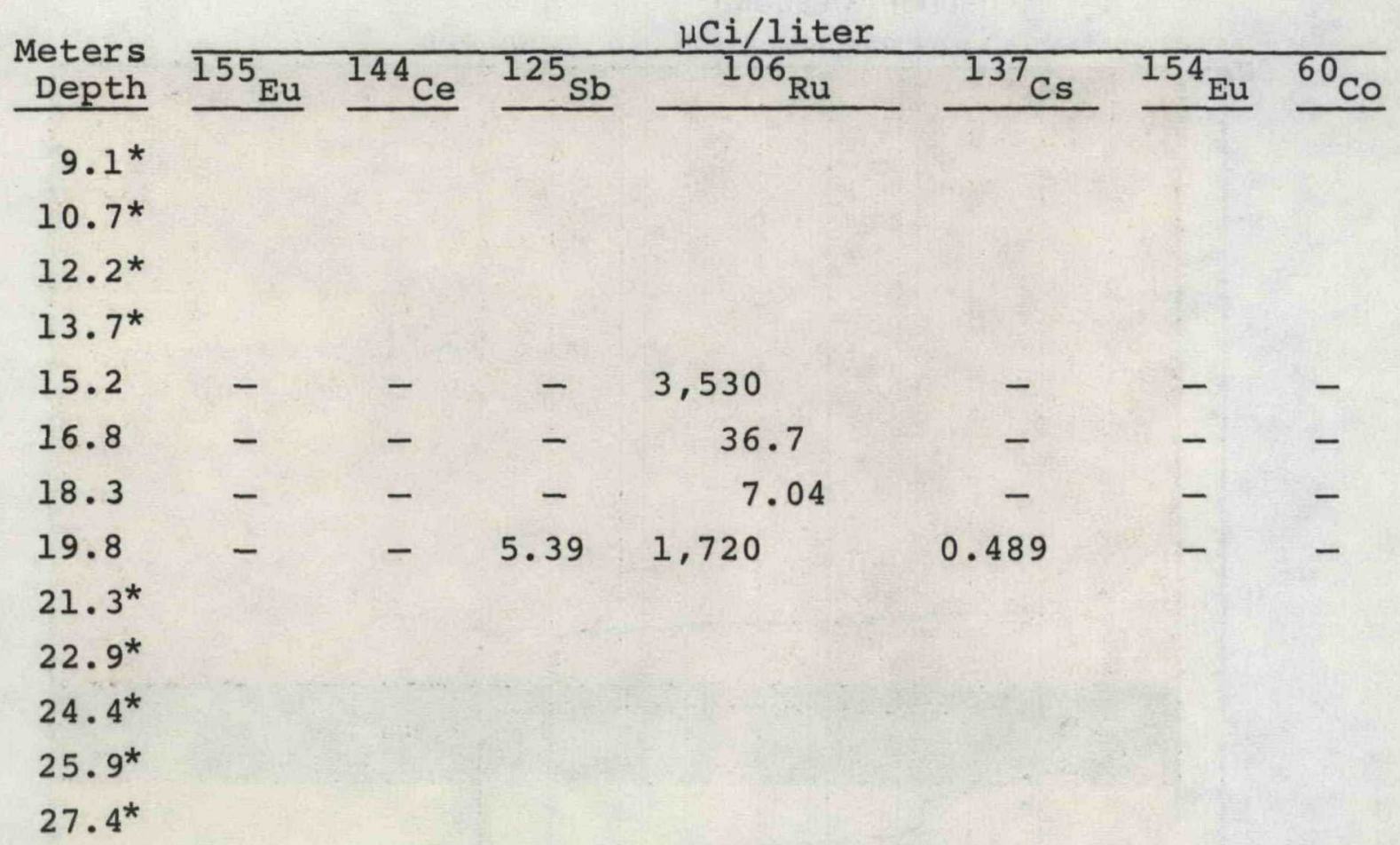

- Radionuclide is absent or below limit of detection. Time Zero is June $21,1973$.

*Samples not submitted to laboratory for analysis. 


\section{LITHOLOGIC DESCRIPTION \& GAMMA LOG} OF INVESTIGATION WELL 299-W10-109

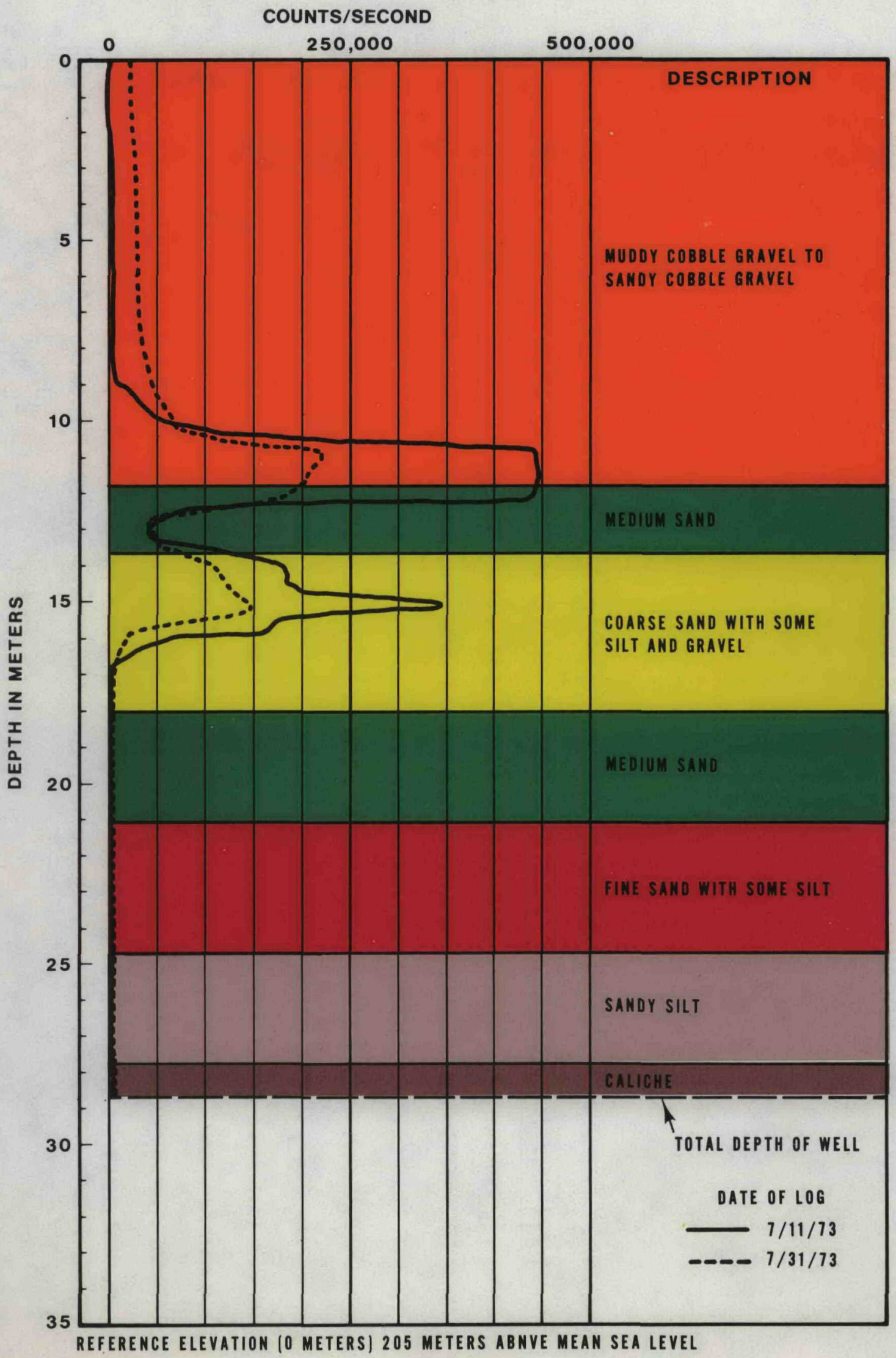


GAMMA ENERGY ANALYSES OF SAMPLES

FROM WELL 299-W10-109

\begin{tabular}{|c|c|c|c|c|c|c|c|}
\hline \multirow{2}{*}{$\begin{array}{r}\text { Meters } \\
\text { Depth }\end{array}$} & \multicolumn{7}{|c|}{$\mu \mathrm{Ci} /$ liter } \\
\hline & ${ }^{155} \mathrm{Eu}$ & $144 \mathrm{Ce}$ & $125 \mathrm{Sb}$ & ${ }^{106} \mathrm{Ru}$ & $137 \mathrm{Cs}$ & ${ }^{154} \mathrm{Eu}$ & ${ }^{60} \mathrm{Co}$ \\
\hline \multicolumn{8}{|l|}{9.1 * } \\
\hline 10.7 & - & - & - & 95.1 & - & - & - \\
\hline 12.2 & 26.4 & 215 & 8.11 & 1,080 & - & 49.0 & 10.0 \\
\hline 13.7 & - & - & - & 4,540 & - & & \\
\hline 15.2 & - & - & - & 4,739 & - & - & - \\
\hline 16.8 & - & - & - & 3.20 & - & - & - \\
\hline 18.3 & - & - & - & 0.133 & - & - & - \\
\hline 19.8 & - & - & - & 0.0344 & - & - & - \\
\hline \multicolumn{8}{|l|}{$21.3^{*}$} \\
\hline \multicolumn{8}{|l|}{$22.9^{*}$} \\
\hline \multicolumn{8}{|l|}{$24.4^{*}$} \\
\hline \multicolumn{8}{|l|}{$25.9^{*}$} \\
\hline $27.4^{*}$ & & & & & & & \\
\hline
\end{tabular}

- Radionuclide is absent or below limit of detection. Time Zero is June $21,1973$.

*Samples not submitted to laboratory for analysis. 


\section{LITHOLOGIC DESCRIPTION \& GAMMA LOG} OF INVESTIGATION WELL

299-W10-110

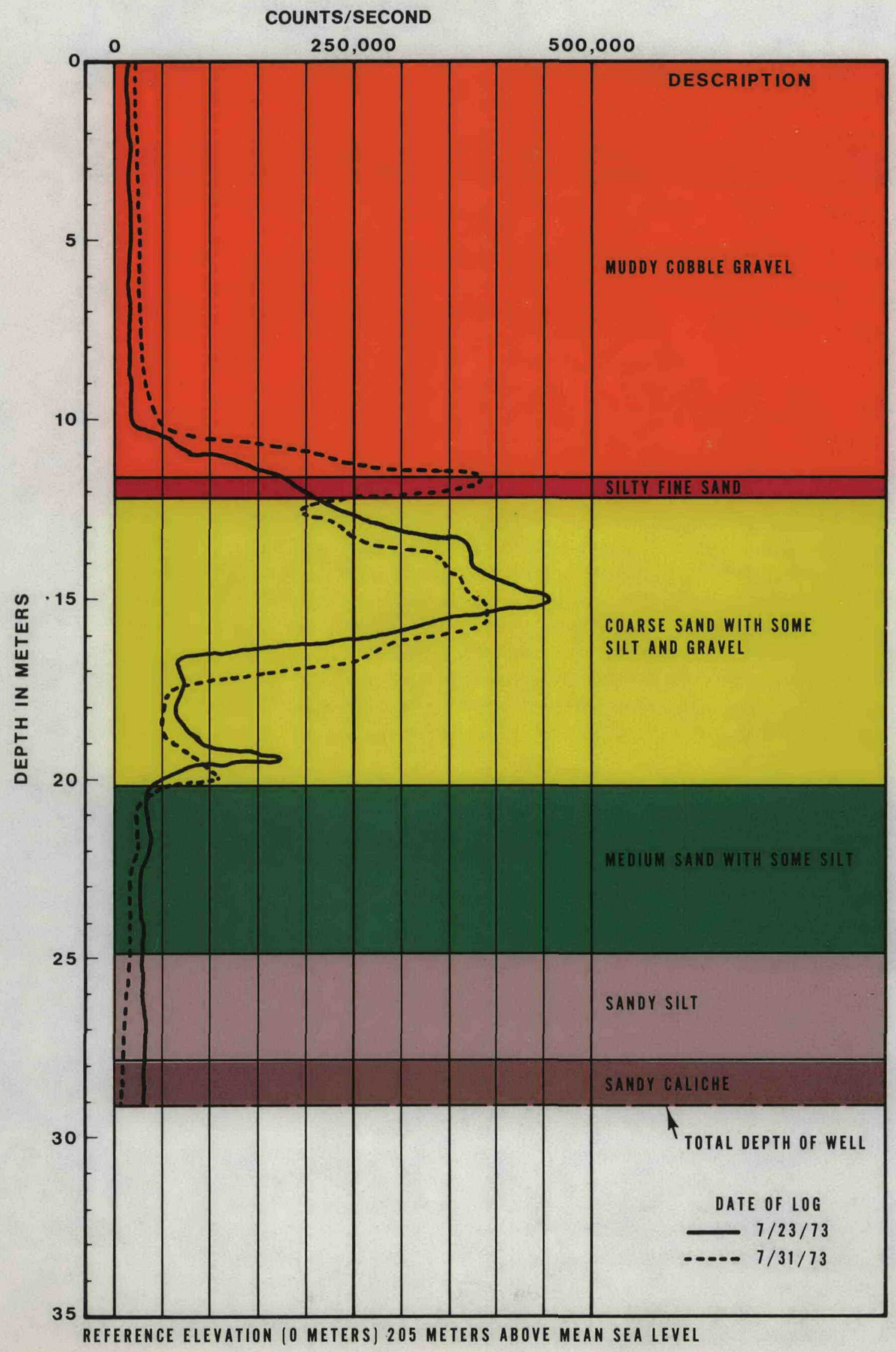


GAMMA ENERGY ANALYSES OF SAMPLES

FROM WELL 299-W10-110

\begin{tabular}{|c|c|c|c|c|c|c|c|}
\hline $\begin{array}{r}\text { Meters } \\
\text { Depth }\end{array}$ & $155_{\mathrm{Eu}}$ & ${ }^{144} \mathrm{Ce}$ & $125 \mathrm{Sb}$ & ${ }^{106} \mathrm{Ru}$ & $137 \mathrm{Cs}$ & ${ }^{154} \mathrm{Eu}$ & ${ }^{60} \mathrm{Co}$ \\
\hline \multicolumn{8}{|l|}{$9.1 *$} \\
\hline 10.7 & - & 155. & 41.5 & 11,400 & - & - & 9.04 \\
\hline 12.2 & - & 43.4 & - & 3,880 & - & - & 3.50 \\
\hline 13.7 & 51.0 & 326 . & 48.3 & 9,130 & - & 12.7 & 5.95 \\
\hline 15.2 & - & 122 . & - & 10,600 & - & - & 4.94 \\
\hline 16.8 & - & - & 2.67 & 896 & - & - & - \\
\hline 18.3 & - & - & - & 0.095 & - & - & - \\
\hline 19.8 & - & - & - & 18.2 & - & - & - \\
\hline 21.3 & - & - & 1.26 & 403 & - & - & - \\
\hline 22.9 & - & $=-$ & - & 0.072 & - & - & - \\
\hline 24.4 & 0.000 & $86-$ & - & 0.0018 & - & - & - \\
\hline \multicolumn{8}{|l|}{$25.9^{\star}$} \\
\hline $27.4^{*}$ & & & & & & & \\
\hline
\end{tabular}

- Radionuclide is absent or below limit of detection.

Time Zero is June $21,1973$.

*Samples not submitted to laboratory for analysis. 


\section{LITHOLOGIC DESCRIPTION \& GAMMA LOG} OF INVESTIGATION WELL

299-W10-111

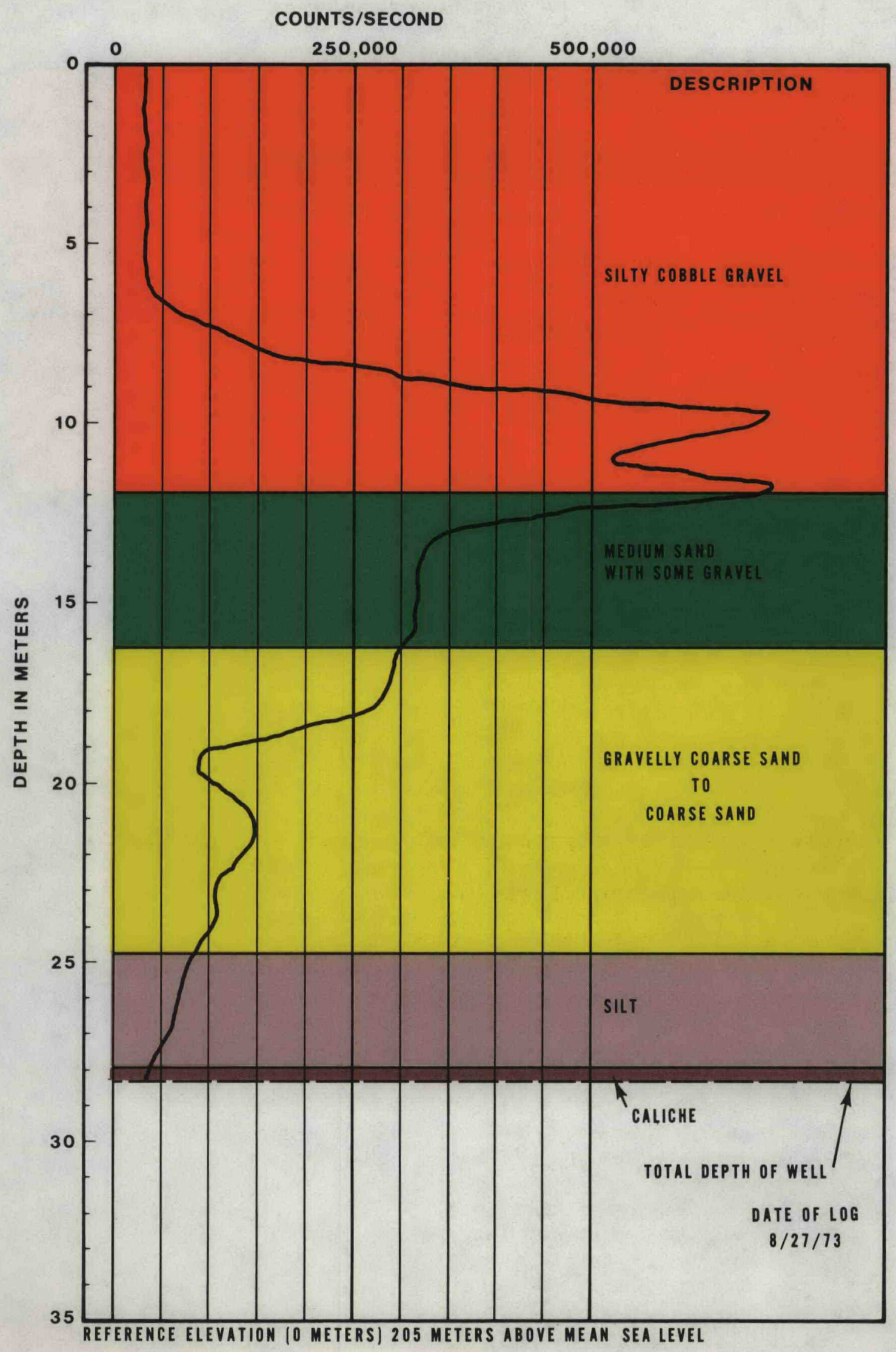


GAMMA ENERGY ANALYSES OF SAMPLES

FROM WELL 299-W10-111

\begin{tabular}{|c|c|c|c|c|c|c|c|}
\hline $\begin{array}{r}\text { Meters } \\
\text { Depth } \\
\end{array}$ & $155 \mathrm{Eu}$ & ${ }^{144} \mathrm{Ce}$ & $125 \mathrm{Sb}$ & $\frac{\mu \mathrm{Ci} / 1 \text { ite }}{{ }^{106} \mathrm{Ru}}$ & ${ }^{137} \mathrm{Cs}$ & ${ }^{154} \mathrm{Eu}$ & ${ }^{60} \mathrm{Co}$ \\
\hline \multicolumn{8}{|l|}{9.1 * } \\
\hline 10.7 & 15.1 & 131. & 5.62 & 324 . & 5.08 & 4.15 & 0.536 \\
\hline 12.2 & 78.8 & 764 . & - & 5,590 & 207 . & - & - \\
\hline 13.7 & 145 . & 1,500 & 110. & 7,840 & 11.9 & 36.3 & - \\
\hline 15.2 & - & - & - & 7,270 & - & - & - \\
\hline 16.8 & - & 373. & - & 11,500 & - & - & - \\
\hline 18.3 & - & - & - & 7,680 & - & - & - \\
\hline 19.8 & - & - & - & 3,140 & - & - & - \\
\hline 21.3 & - & - & - & 2,540 & - & - & - \\
\hline 22.9 & - & - & - & 750 . & - & - & - \\
\hline \multicolumn{8}{|l|}{$24.4^{*}$} \\
\hline \multicolumn{8}{|l|}{$25.9^{*}$} \\
\hline $27.4^{*}$ & & & & & & & \\
\hline
\end{tabular}

- Radionuclide is absent or below limit of detection.

Time Zero is June 21, 1973.

*Samples not submitted to laboratory for analysis. 


\section{LITHOLOGIC DESCRIPTION \& GAMMA LOG} OF INVESTIGATION WELL

299-W10-112

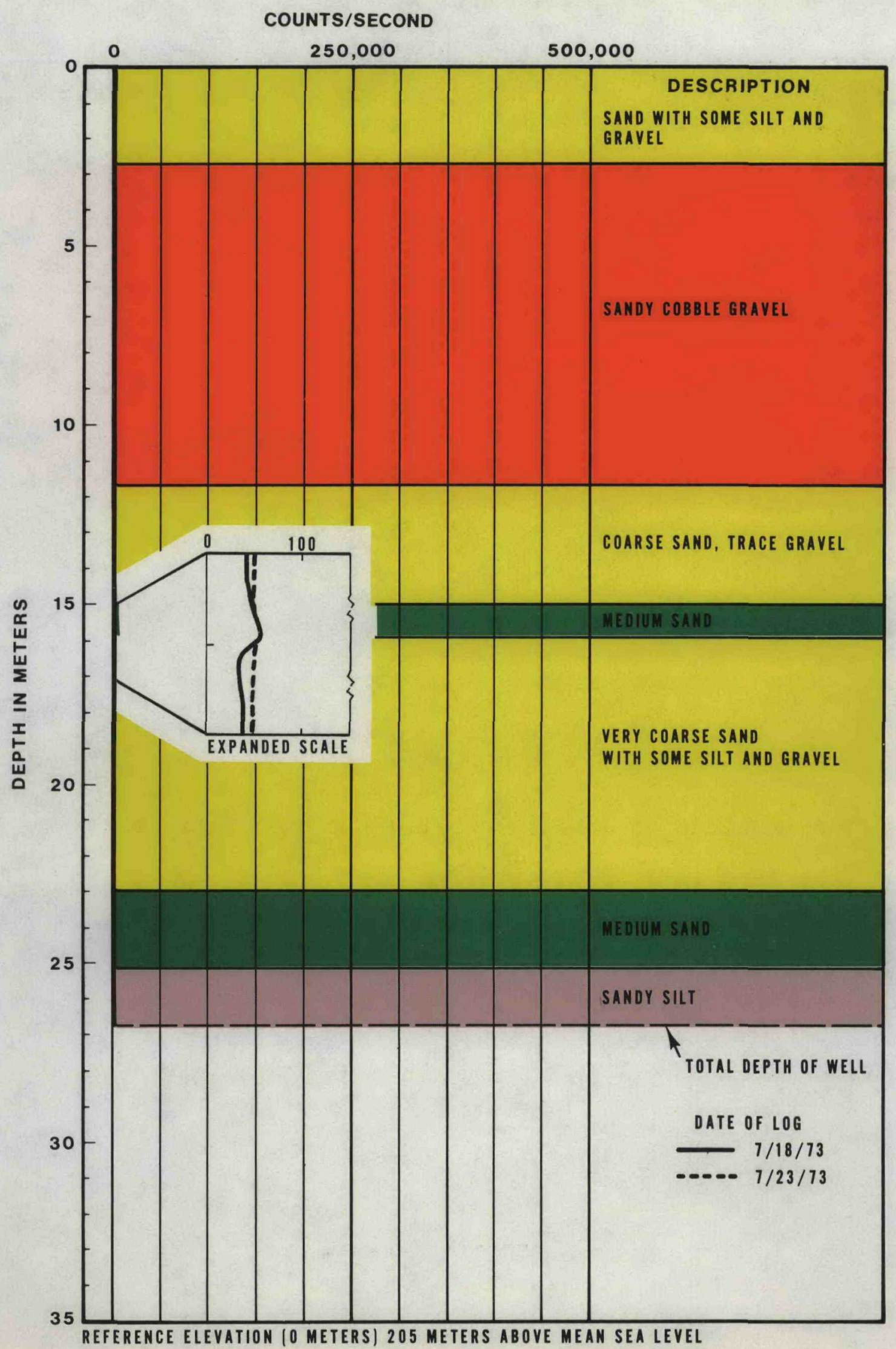


GAMMA ENERGY ANALYSES OF SAMPLES

FROM WELL 299-W10-112

Gamma well logs indicated no radioactivity in the well, consequently samples from the well were not submitted for gamma-energy analysis. 
LITHOLOGIC DESCRIPTION \& GAMMA LOG OF INVESTIGATION WELL

\section{9-W10-113}

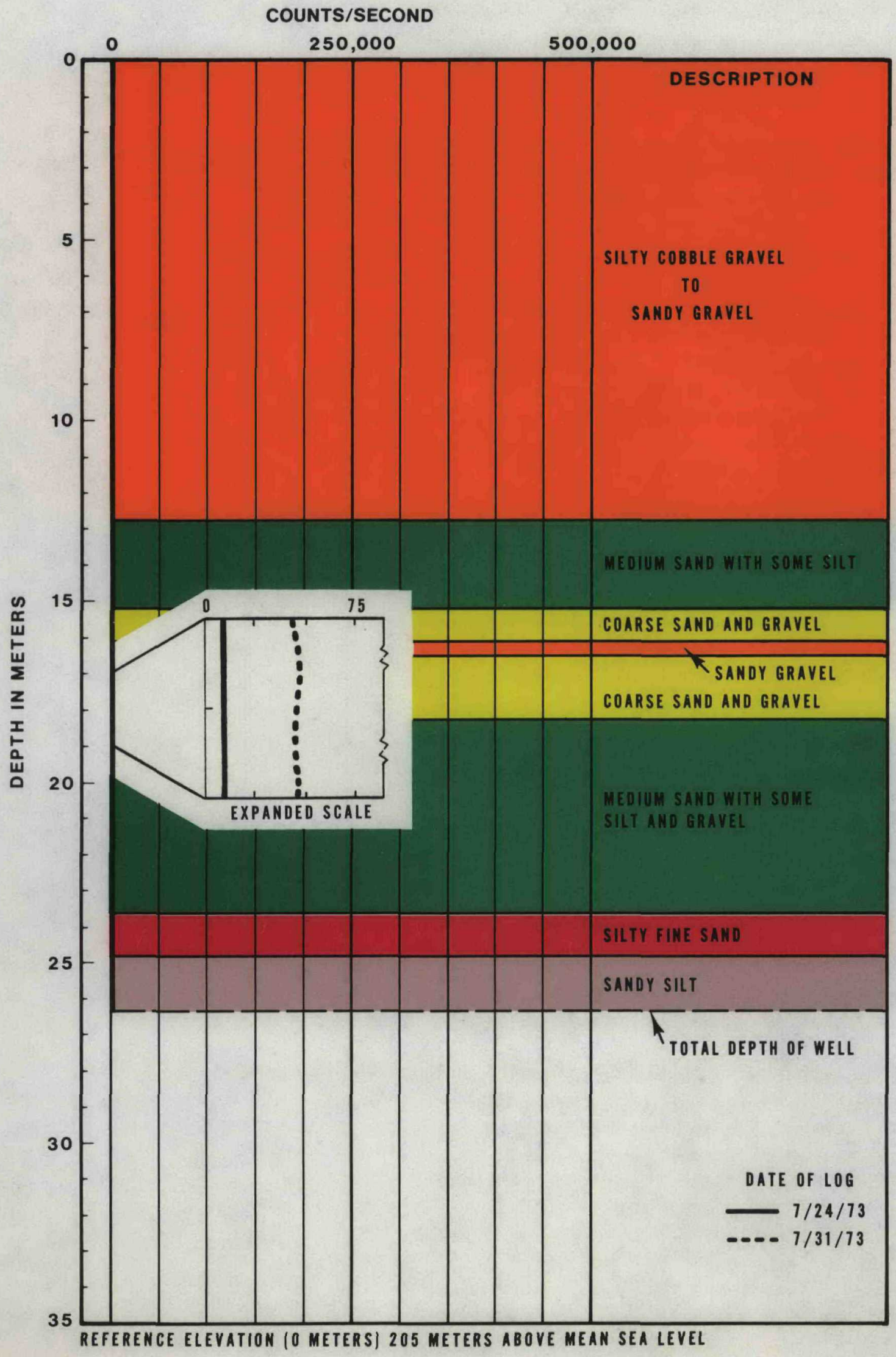


GAMMA ENERGY ANALYSES OF SAMPLES

FROM WELL 299-W10-113

Gamma well logs indicated no radioactivity in the well, consequently samples from the well were not submitted for gamma-energy analysis. 


\section{LITHOLOGIC DESCRIPTION \& GAMMA LOG} OF INVESTIGATION WELL

299-W10-114

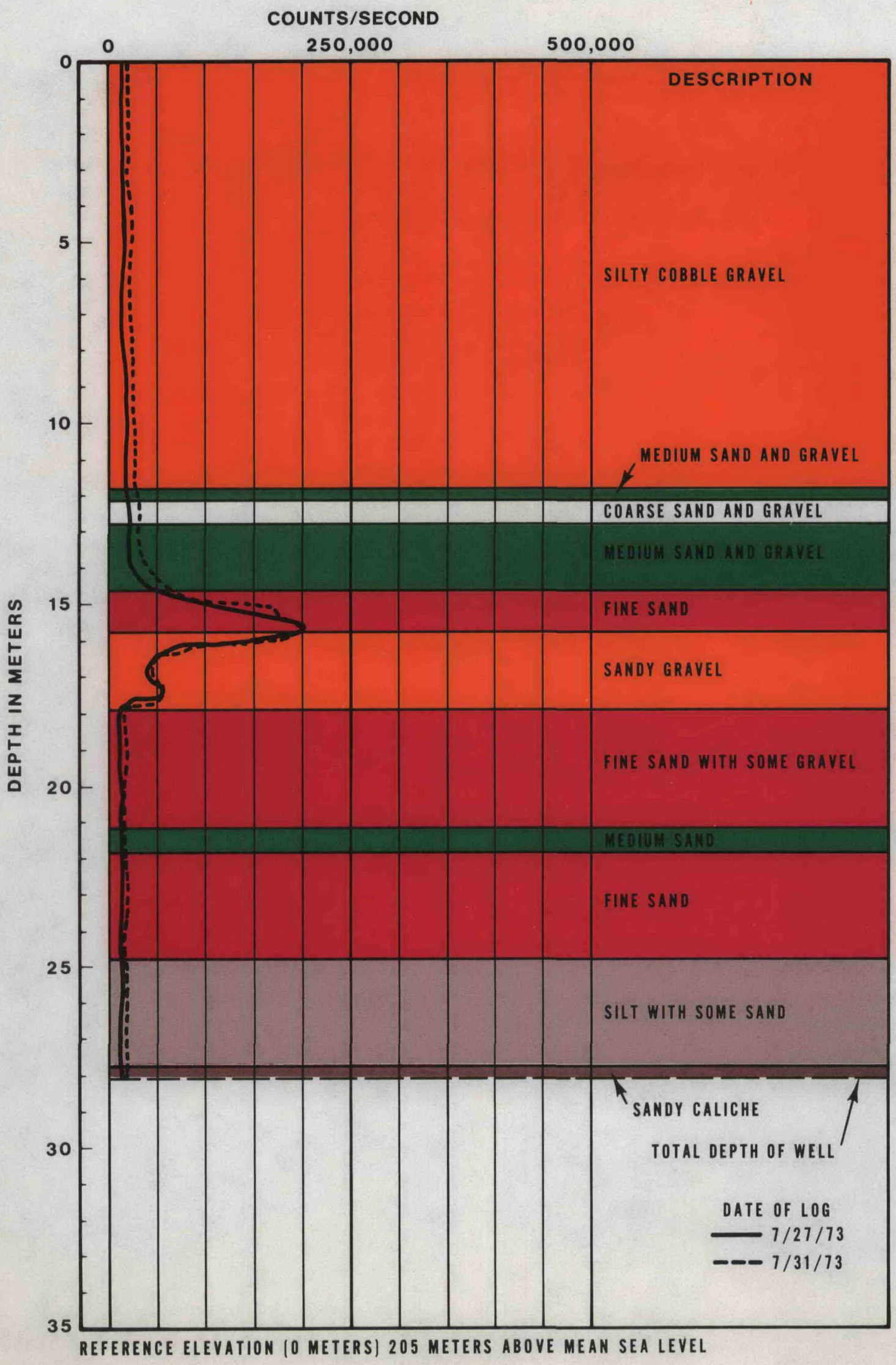




\section{GAMMA ENERGY ANALYSES OF SAMPLES}

FROM WELL 299-W10-114

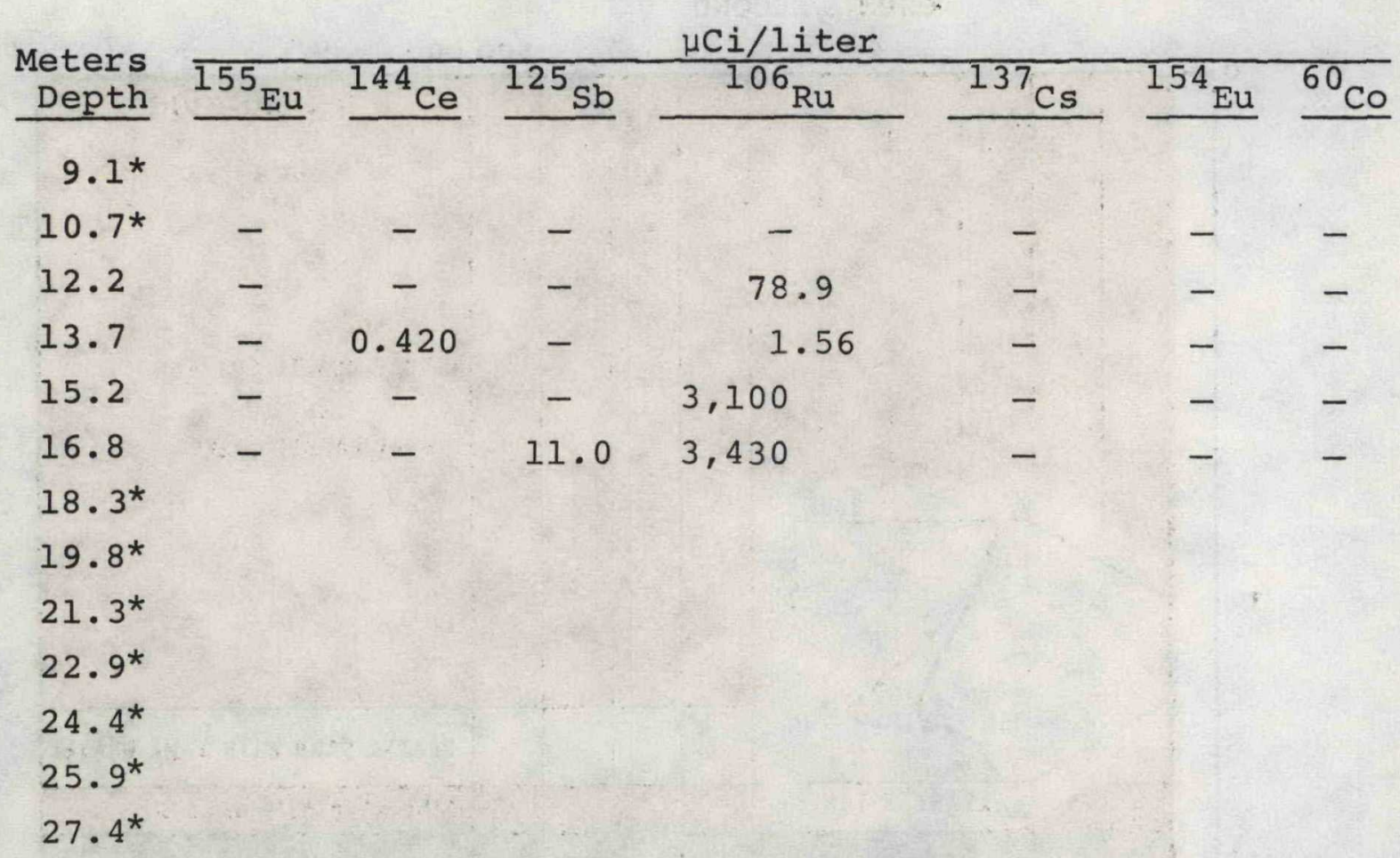

- Radionuclide is absent or below limit of detection. Time Zero is June $21,1973$.

*Samples not submitted to laboratory for analysis. 
LITHOLOGIC DESCRIPTION \& GAMMA LOG OF INVESTIGATION WELL

299-W10-115

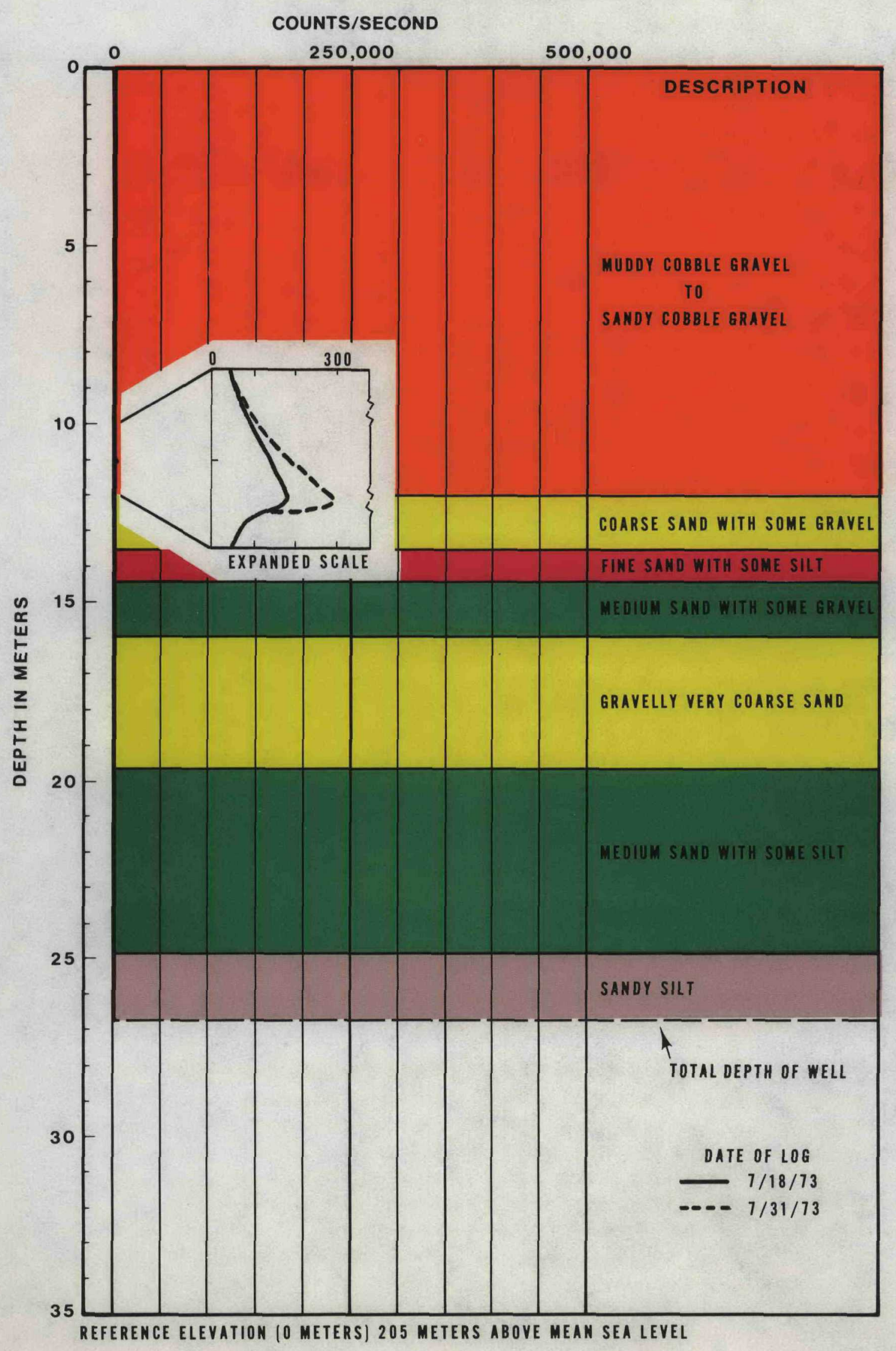




\section{GAMMA ENERGY ANALYSES OF SAMPLES}

FROM WELI 299-W10-115

Samples from this well were not submitted for gamma-energy analysis. 
LITHOLOGIC DESCRIPTION \& GAMMA LOG OF INVESTIGATION WELL

\section{9-W10-116}

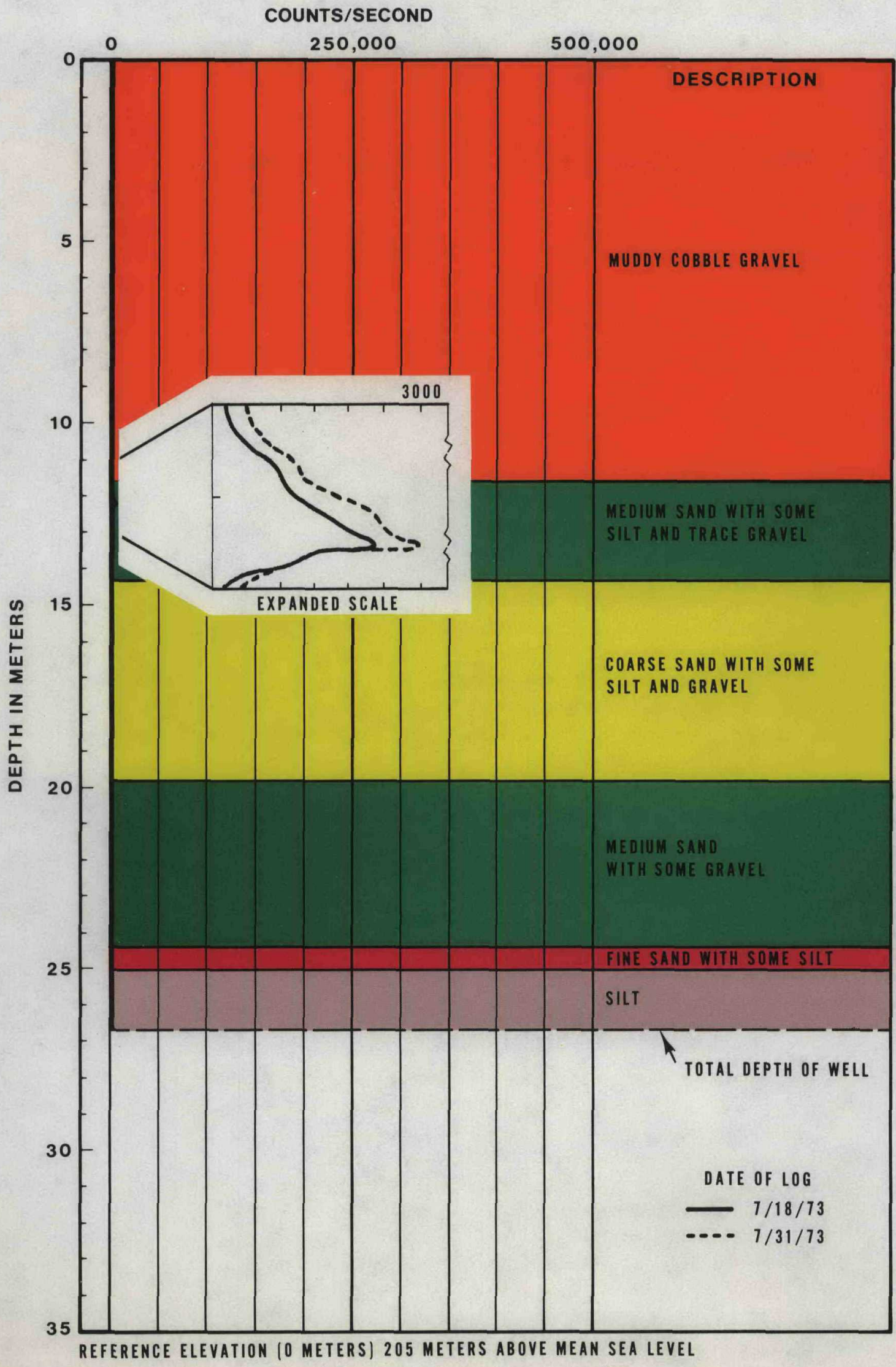


GAMMA ENERGY ANALYSES OF SAMPLES

FROM WELL 299-W10-116

Samples from this well were not submitted for gamma-energy analysis. 
LITHOLOGIC DESCRIPTION \& GAMMA LOG OF INVESTIGATION WELL 299-W10-117

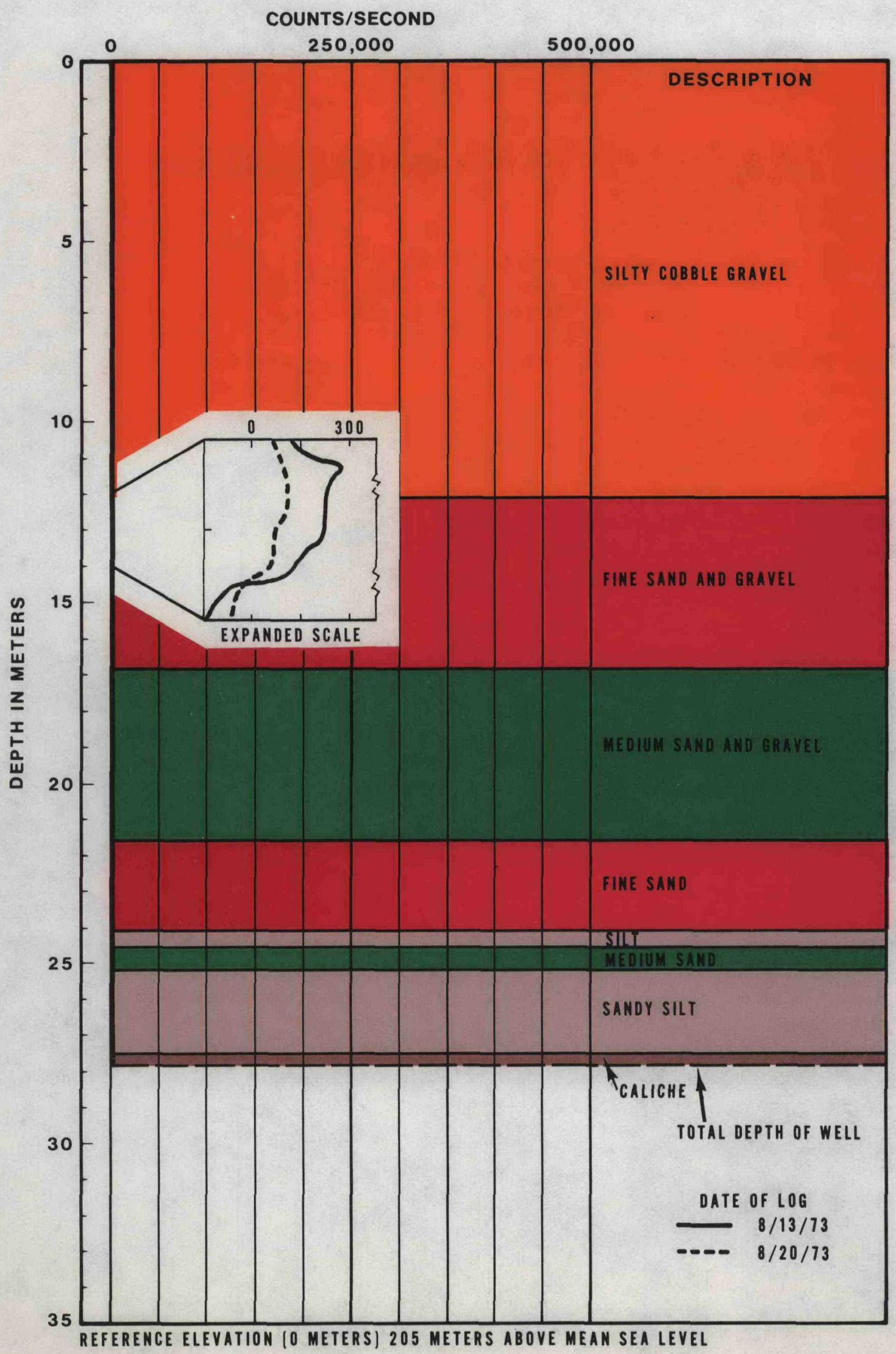


GAMMA ENERGY ANALYSES OF SAMPLES

FROM WELL 299-W10-117

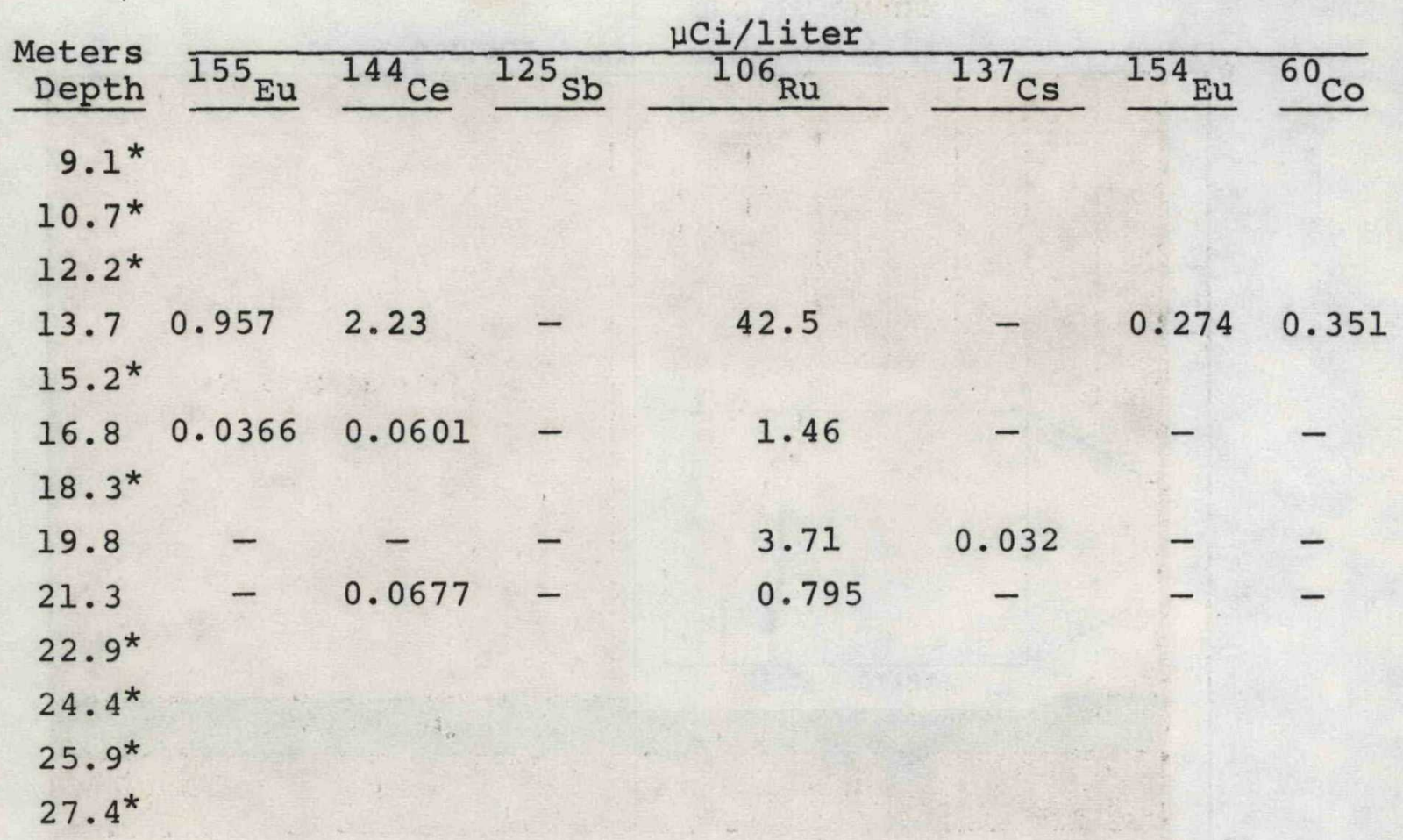

- Radionuclide is absent or below limit of detection. Time Zero is June $21,1973$.

*Samples not submitted to laboratory for analysis. 
LITHOLOGIC DESCRIPTION \& GAMMA LOG OF INVESTIGATION WELL

299-W10-118

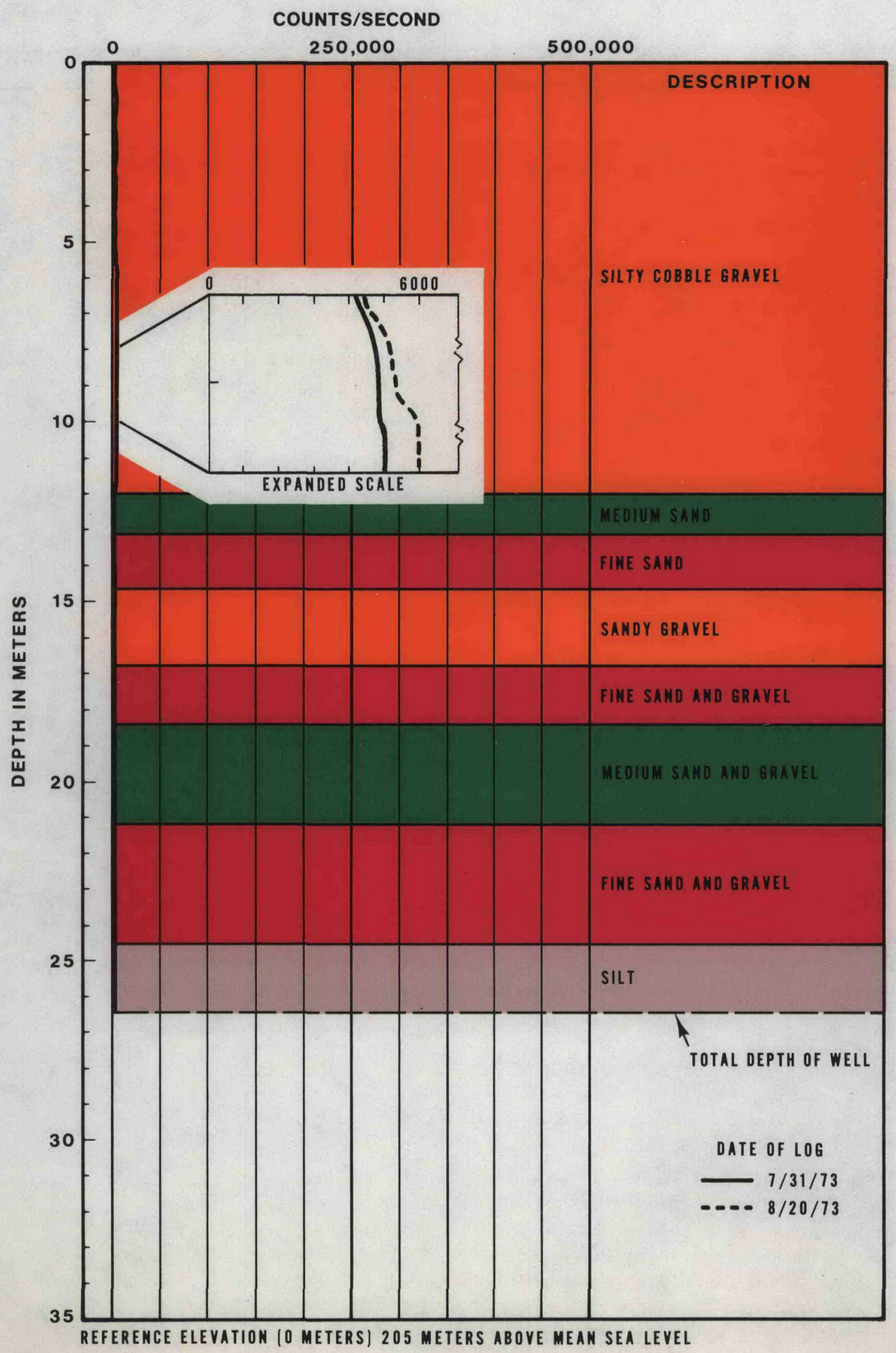


GAMMA ENERGY ANALYSES OF SAMPLES

FROM WELL 299-W10-118

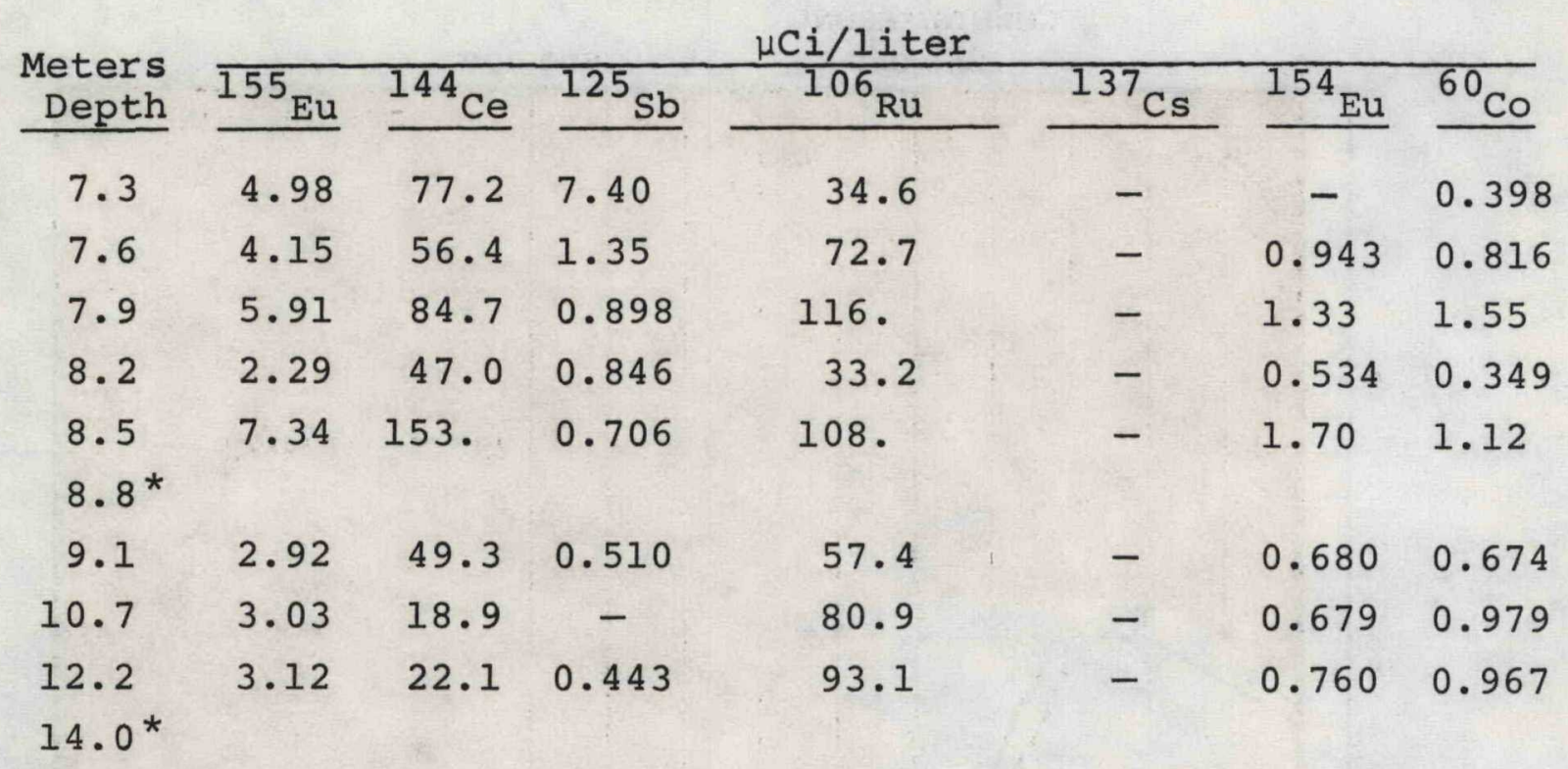

- Radionuclide is absent or below limit of detection. Time Zero is June 21, 1973.

*Samples not submitted to laboratory for analysis. 


\section{A-27 \\ ARH-2874 \\ LITHOLOGIC DESCRIPTION \& GAMMA LOG OF INVESTIGATION WELL 299-W10-119}

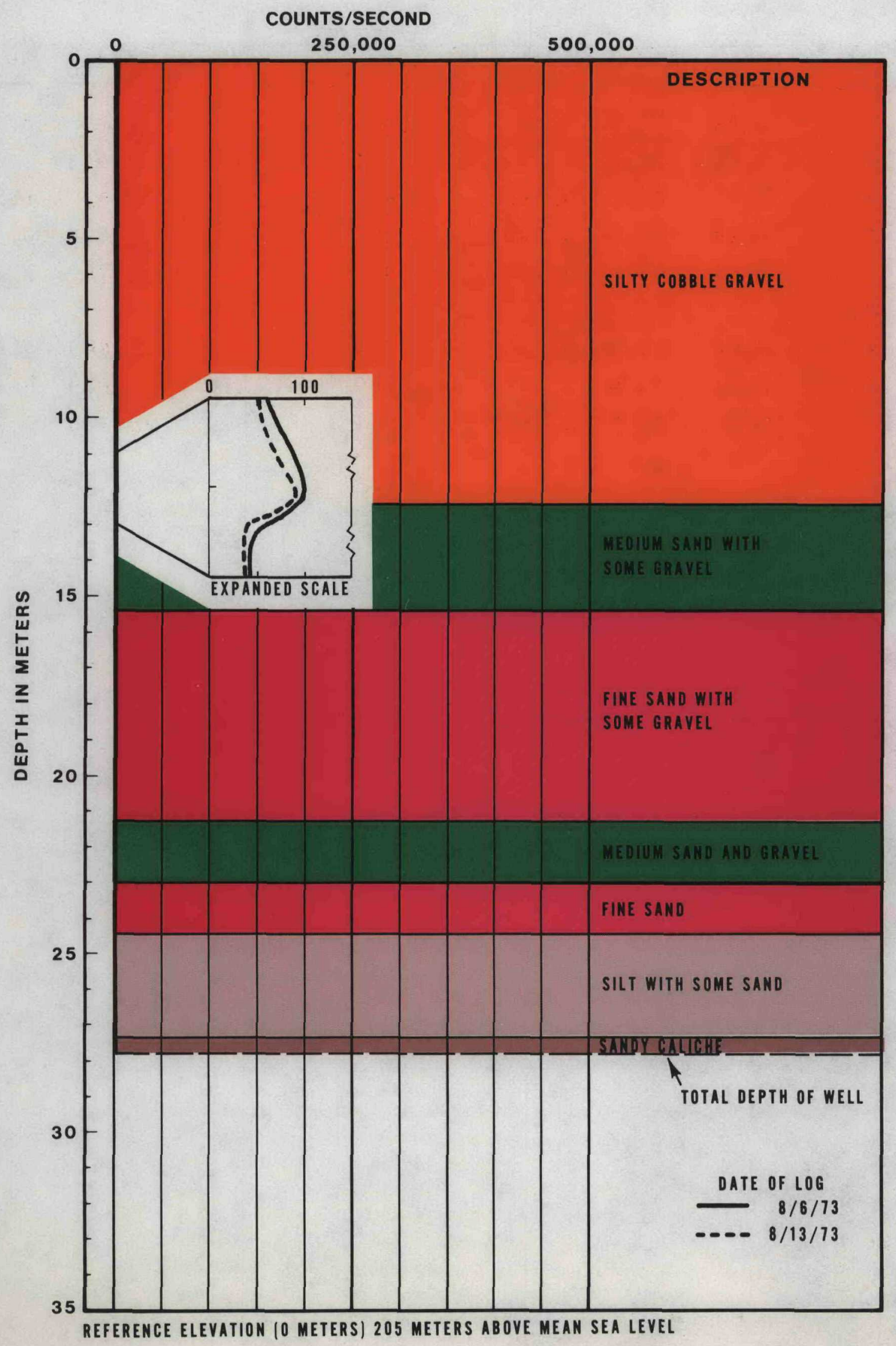


GAMMA ENERGY ANALYSES OF SAMPLES

FROM WELL 299-W10-119

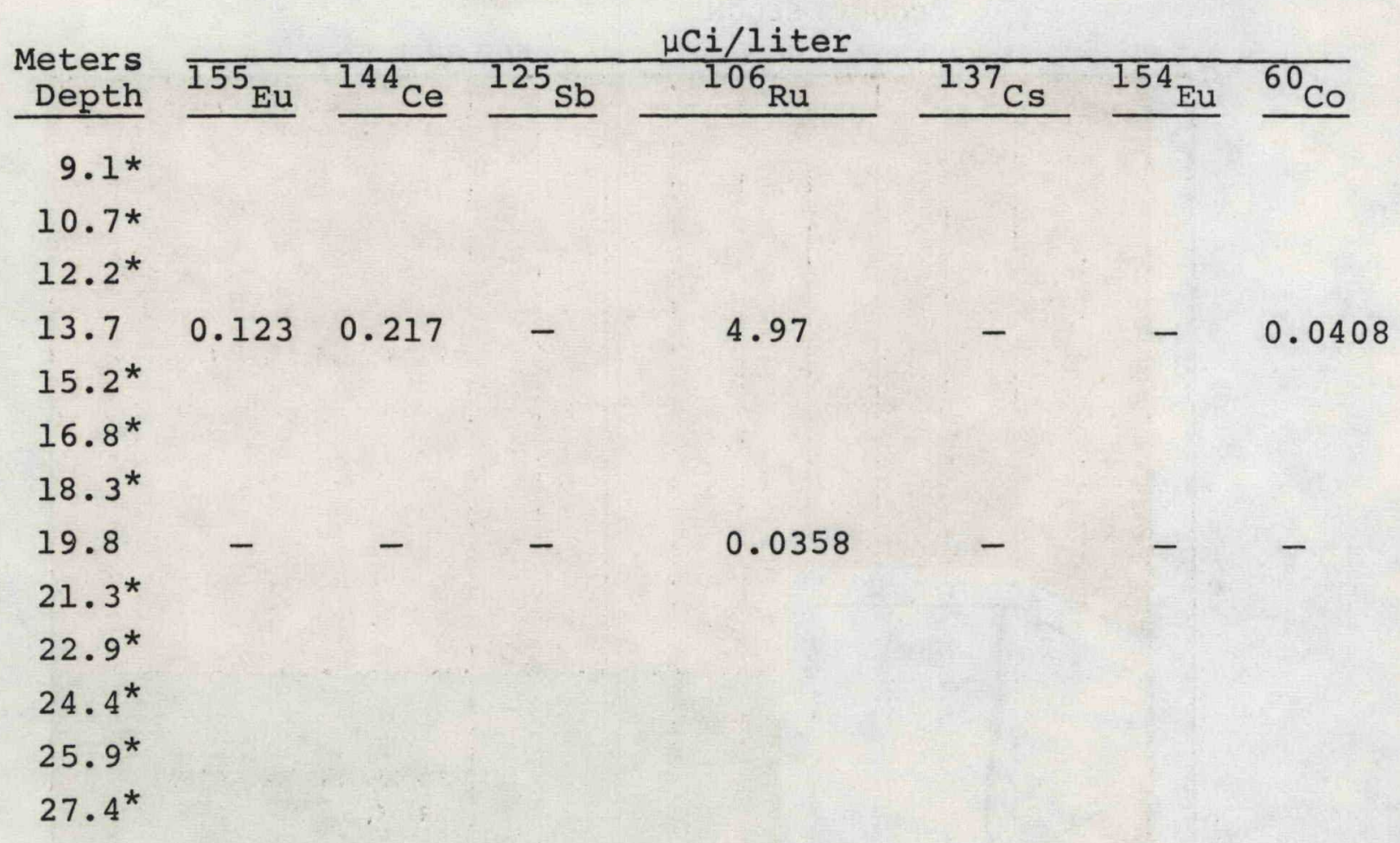

- Radionuclide is absent or below limit of detection.

Time Zero is June 21, 1973.

*Samples not submitted to laboratory for analysis. 
LITHOLOGIC DESCRIPTION \& GAMMA LOG OF INVESTIGATION WELL 299-W10-120

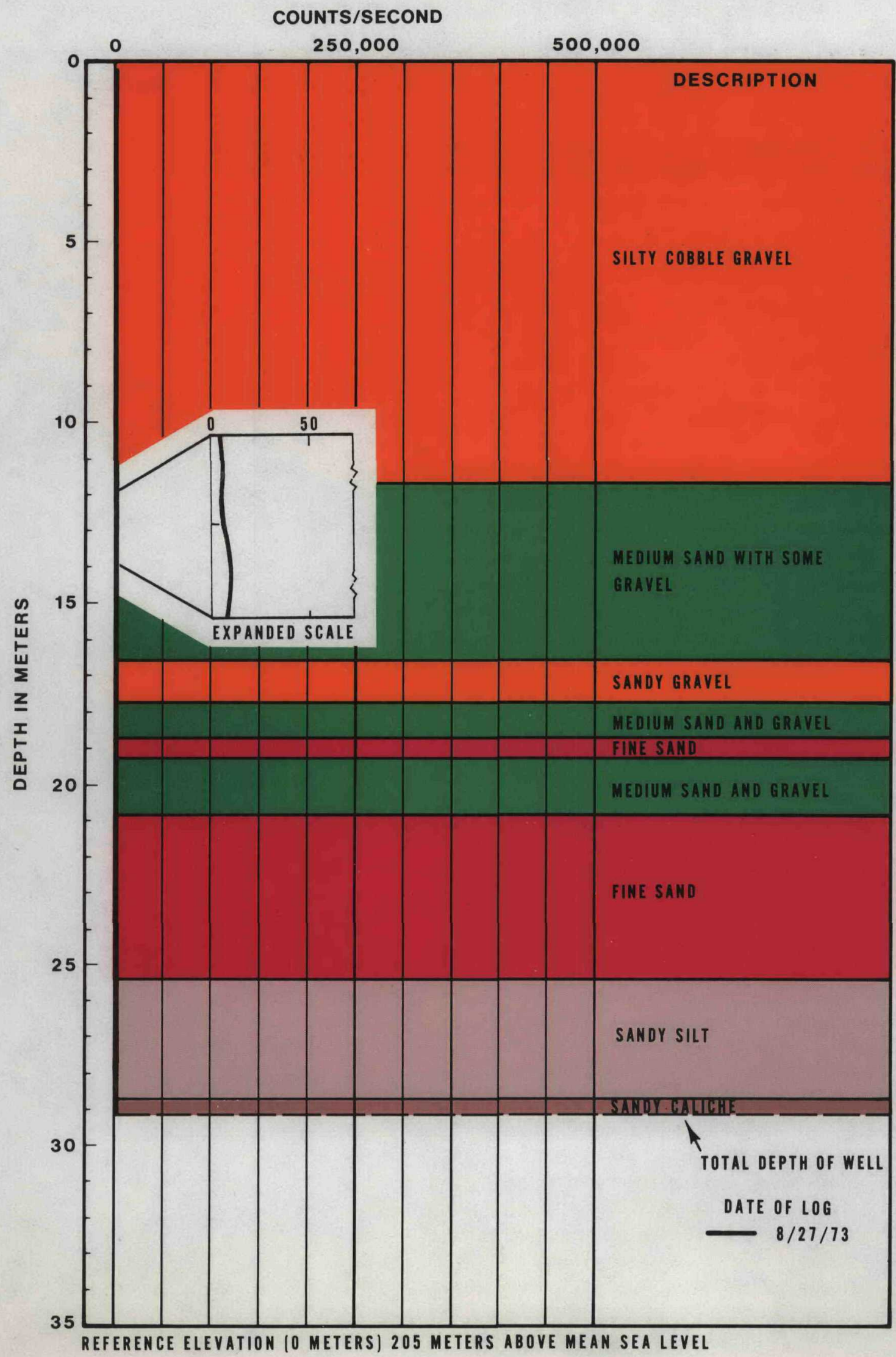


GAMMA ENERGY ANALYSES OF SAMPLES

FROM WELL 299-W10-120

Gamma well logs indicated no radioactivity in the well, consequently samples from the well were not submitted for gamma-energy analysis. 
LITHOLOGIC DESCRIPTION \& GAMMA LOG OF INVESTIGATION WELL

299-W10-121

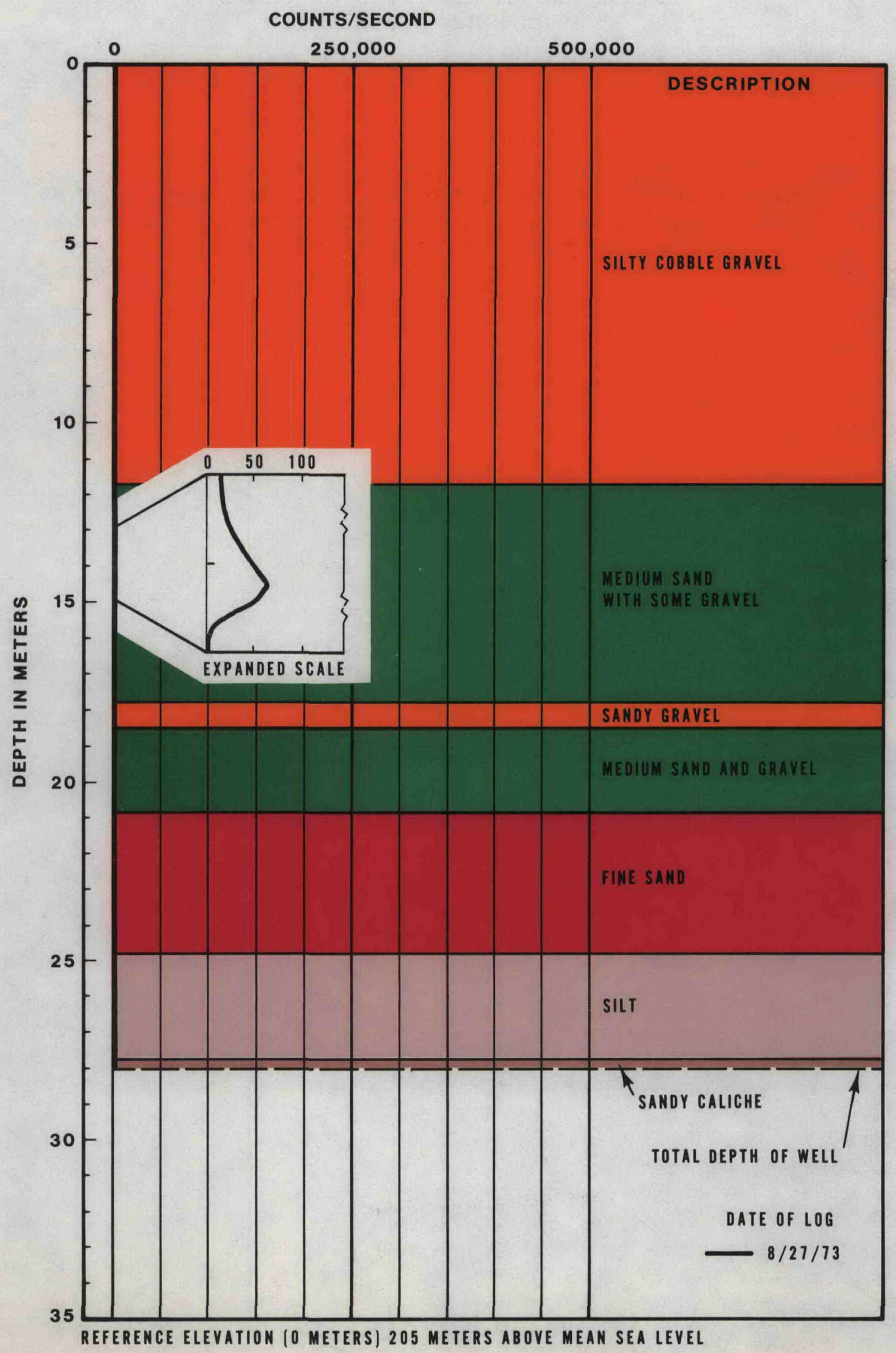


GAMMA ENERGY ANALYSES OF SAMPLES

FROM WELL 299-W10-121

Samples from this well were not submitted for gamma-energy analysis. 
LITHOLOGIC DESCRIPTION \& GAMMA LOG OF INVESTIGATION WELL

\section{9-W10-51}

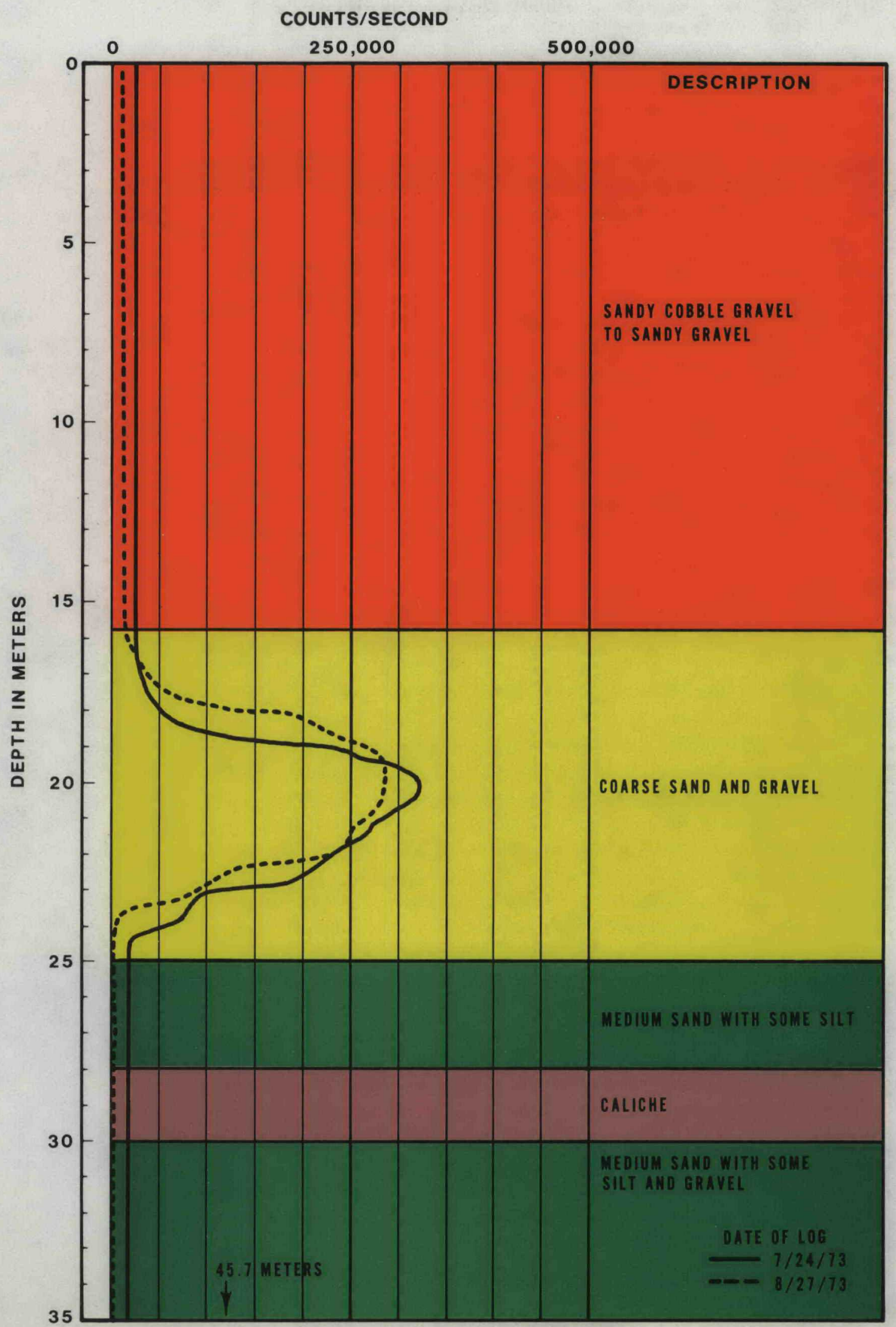

TOTAL. DEPTH OF WELL 45.7 METERS

REFERENCE ELEVATION (O METERS) 205 METERS ABOVE MEAN SEA LEVEL 